\title{
Mantle-derived trace element variability in olivines and their melt inclusions
}

DOI:

10.1016/j.epsl.2017.12.014

\section{Document Version}

Accepted author manuscript

Link to publication record in Manchester Research Explorer

\section{Citation for published version (APA):}

Neave, D. A., Shorttle, O., Oeser, M., Weyer, S., \& Kobayashi, K. (2018). Mantle-derived trace element variability in olivines and their melt inclusions. Earth and Planetary Science Letters, 483, 90-104.

https://doi.org/10.1016/j.epsl.2017.12.014

\section{Published in:}

Earth and Planetary Science Letters

\section{Citing this paper}

Please note that where the full-text provided on Manchester Research Explorer is the Author Accepted Manuscript or Proof version this may differ from the final Published version. If citing, it is advised that you check and use the publisher's definitive version.

\section{General rights}

Copyright and moral rights for the publications made accessible in the Research Explorer are retained by the authors and/or other copyright owners and it is a condition of accessing publications that users recognise and abide by the legal requirements associated with these rights.

\section{Takedown policy}

If you believe that this document breaches copyright please refer to the University of Manchester's Takedown Procedures [http://man.ac.uk/04Y6Bo] or contact uml.scholarlycommunications@manchester.ac.uk providing relevant details, so we can investigate your claim.

\section{OPEN ACCESS}




\title{
Mantle-derived trace element variability in olivines and their melt inclusions
}

\author{
David A. Neave ${ }^{\mathrm{a}, *}$, Oliver Shorttle ${ }^{\mathrm{b}, \mathrm{c}, \mathrm{d}}$, Martin Oeser ${ }^{\mathrm{a}}$, Stefan Weyer $^{\mathrm{a}}$, Katsura Kobayashi ${ }^{\mathrm{d}}$ \\ ${ }^{a}$ Leibniz Universität Hannover, Institut für Mineralogie, Callinstraße 3, 30167 Hannover, Germany \\ ${ }^{b}$ Department of Earth Sciences, University of Cambridge, Downing Street, Cambridge, CB2 3EQ, United \\ Kingdom \\ ${ }^{c}$ Institute of Astronomy, University of Cambridge, Madingley Road, Cambridge, CB3 0HA, United \\ Kingdom \\ ${ }^{d}$ The Pheasant Memorial Laboratory for Geochemistry and Cosmochemistry, Institute for the Study of the \\ Earth's Interior, Okayama University, Misasa, 682-0193, Japan
}

\begin{abstract}
Trace element variability in oceanic basalts is commonly used to constrain the physics of mantle melting and the chemistry of Earth's deep interior. However, the geochemical properties of mantle melts are often overprinted by mixing and crystallisation processes during ascent and storage. Studying primitive melt inclusions offers one solution to this problem, but the fidelity of the melt-inclusion archive to bulk magma chemistry has been repeatedly questioned. To provide a novel check of the melt inclusion record, we present new major and trace element analyses from olivine macrocrysts in the products of two geographically proximal, yet compositionally distinct, primitive eruptions from the Reykjanes Peninsula of Iceland. By combining these macrocryst analyses with new and published melt inclusion analyses we demonstrate that olivines have similar patterns of incompatible trace element (ITE) variability to the inclusions they host, capturing both intra- and inter-eruption scale chemical systematics.

ITE variability (element concentrations, ratios, variances and variance ratios) in olivines from the ITE-enriched Stapafell eruption is best accounted for by olivine-dominated fractional crystallisation. In contrast, ITE variability in olivines and inclusions from the ITEdepleted Háleyjabunga eruption cannot be explained by crystallisation alone, and must have originated in the mantle. Compatible trace element (CTE) variability is best described by crystallisation processes in both eruptions. Modest correlations between host and inclusion
\end{abstract}


ITE contents in samples from Háleyjabunga suggest that melt inclusions can be faithful archives of melting and magmatic processes. It also indicates that degrees of ITE enrichment can be estimated from olivines directly when melt inclusion and matrix glass records of geochemical variability are poor or absent. Inter-eruption differences in olivine ITE systematics between Stapafell and Háleyjabunga mirror differences in melt inclusion suites, and confirm that the Stapafell eruption was fed by lower degree melts from greater depths within the melting region than the Háleyjabunga eruption.

Although olivine macrocrysts from Stapafell are slightly richer in Ni than those from Háleyjabunga, their overall CTE systematics (e.g., Ni/(Mg/Fe), Fe/Mn and $\mathrm{Zn} / \mathrm{Fe}$ ) are inconsistent with being derived from olivine-free pyroxenites. However, the major element systematics of Icelandic basalts require lithological heterogeneity in their mantle source in the form of Fe-rich and hence fusible domains. We thus conclude that enriched heterogeneities in the Icelandic mantle are composed of modally enriched, yet nonetheless olivine-bearing, lithologies and that olivine CTE contents provide an incomplete record of lithological heterogeneity in the mantle. Modally enriched peridotites may therefore play a more important role in oceanic magma genesis than previously inferred.

Keywords: olivine, melt inclusions, trace elements, mantle heterogeneity, geochemical variability, Iceland

${ }^{*}$ Leibniz Universität Hannover, Institut für Mineralogie, Callinstraße 3, 30167 Hannover, Germany, +49 (0)511 762-2564

Email address: d.neave@mineralogie.uni-hannover.de (David A. Neave) 


\section{Introduction}

Fractional melting of a chemically, isotopically and lithologically heterogeneous mantle results in compositionally diverse oceanic basalts (Dupré and Allègre, 1983; Hirschmann and Stolper, 1996; Kelemen et al., 1997; Sobolev et al., 2007; Shorttle et al., 2014). However, geochemical records of mantle heterogeneity are subject to progressive degradation as melts undergo concurrent mixing and crystallisation during ascent (Maclennan, 2008a; Rubin et al., 2009; Shorttle, 2015). Assimilation, reactive porous flow and repeated replenishment, mixing and tapping of steady state reservoirs may all further contribute to the blurring and overprinting of mantle signals (O'Hara, 1977; Langmuir, 1989; Michael and Schilling, 1989; Lissenberg and MacLeod, 2016; O'Neill and Jenner, 2016). Melt inclusions trapped within primitive macrocrysts nevertheless provide glimpses into the compositional systematics of primary melts because they are theoretically insulated from changes in external magmatic environments. For example, melt inclusion suites frequently preserve greater variability in trace element and isotope compositions than the melts that carry them (Sobolev and Shimizu, 1993; Maclennan, 2008b). However, the ability of melt inclusions to faithfully record primary magmatic signals has been repeatedly questioned because of their susceptibility to syn- and post-entrapment modification (e.g., Roedder, 1979; Qin et al., 1992; Danyushevsky et al., 2000, 2004; Baker, 2008).

Geochemical variability is also recorded in macrocryst compositions (e.g., Davidson and Tepley, 1997; Winpenny and Maclennan, 2011; Foley et al., 2013). For example, elevated Ni and $\mathrm{Fe} / \mathrm{Mn}$ in primitive magmatic olivines have been interpreted as evidence for melt supply from olivine-free mantle domains by some workers (Sobolev et al., 2005, 2007; Herzberg, 2011), though separating the effects of source and process on these elements' systematics remains difficult (Putirka et al., 2011; Matzen et al., 2013; Herzberg et al., 2016; Lynn et al., 2017). One reason for this difficulty is that incompatible trace element (ITE) datasets, which are primarily obtained from melt inclusions, are seldom integrated with compatible trace element (CTE) datasets, which are primarily acquired from olivines, despite the fact that both datasets contain complimentary forms of magmatic information: in principle, ITEs are 
more sensitive to melting processes while CTEs are more sensitive to source compositions (Le Roux et al., 2011). However, the ITE data from natural olivines which could facilitate integration of the olivine and melt inclusion archives are currently scarce, largely because the challenges associated with performing routine in situ microanalysis of trace elements at ppb levels are only now being overcome (e.g., Stead et al., 2016).

In this study, we combine analyses of ITEs and CTEs in olivine macrocrysts with new and published analyses of ITEs in melt inclusions to validate the reliability of melt inclusion archives (cf., Danyushevsky et al., 2004). We thus consider whether degrees of magmatic ITE enrichment can be estimated from olivines directly in samples where no analysable inclusions are present and assessments of geochemical variability are consequently restricted. We then investigate whether compositional variability in forsteritic olivines and their inclusions is dominated by processes taking place in the mantle (i.e. melting) or the crust (i.e. crystallisation). By focusing on two spatially associated yet variably enriched primitive eruptions from Iceland, we investigate how olivine and melt inclusion records of geochemical variability manifest on intra- and inter-eruption scales. We pay particular attention to variance in our compositional data and describe how this underexploited property of geochemical datasets can be used to determine the causes of trace element variability and hence study geological processes. Finally, we evaluate whether olivine CTE contents serve as faithful indicators of lithological heterogeneity in the mantle more widely, and discuss the role played by olivine-free source regions in the generation of Icelandic magmas.

\section{Geochemical context and sample preparation}

The Reykjanes Peninsula of Iceland is an ideal location for studying the generation and evolution of oceanic basalts because primitive lavas are highly abundant (Jakobsson et al., 1978; Thirlwall et al., 2004). The Háleyjabunga lava shield and Stapafell table mountain in the Reykjanes-Svartsengi volcanic system at the south-western tip of the peninsula (Fig. 1a) have proven to be especially valuable for understanding the geochemical consequences of mantle melting (Gurenko and Chaussidon, 1995; Maclennan, 2008b). Despite their spatial proximity and similar ages, these eruptions have strikingly different whole-rock trace 
element chemistries (Hémond et al., 1993; Hardarson et al., 1997; Thirlwall et al., 2004, 2006; Peate et al., 2009): Háleyjabunga and Stapafell are among the most ITE-depleted and ITE-enriched eruptions known from Iceland respectively (Fig. 1b; Gurenko and Chaussidon, 1995). These two eruptions are therefore ideal targets for testing whether variability in magmatic ITE enrichment can be resolved in the composition of olivine macrocrysts.

The difference in ITE enrichment between Háleyjabunga and Stapafell, which is as well shown in melt inclusions as in whole-rock samples (Figs. 2a), has been explained as a consequence of fractional melting in a single mantle column (Gurenko and Chaussidon, 1995). Namely, Gurenko and Chaussidon (1995) argued that ITE-depleted compositions represent instantaneous fractional melts formed by 17-18\% melting of a spinel lherzolite source, while ITE-enriched compositions represent mixtures of ITE-depleted melts and enriched melts formed by $5.5 \%$ melting of a garnet lherzolite source. Moreover, the Stapafell eruption's comparatively low $\mathrm{MgO}$ content is unlikely to represent a greater degree of magmatic differentiation alone: ITE-enriched primitive basalts have consistently lower $\mathrm{MgO}$ contents than their ITE-depleted counterparts, further reflecting differences in mantle melting conditions (Shorttle et al., 2016). Maclennan (2008b) demonstrated that ITE enrichment in melt inclusions correlates with Pb-isotope enrichment (Figs. 2b), reproducing correlations identified in whole-rock datasets, and extending them towards more depleted compositions (cf., Thirlwall et al., 2004). These published correlations between ITE and Pb-isotope ratios imply that fine-scale heterogeneities in the mantle source also contribute to the geochemical variability expressed on the Reykjanes Peninsula: fractional melting alone cannot generate the full spectrum of isotopic diversity reported, and the Icelandic crust is too young to have ingrown enough $\mathrm{Pb}$-isotope variability to significantly contaminate magmatic signatures by assimilation (exposed crust is $<3.3$ Ma on the Reykjanes Peninsula; Jóhannesson and Sæmundsson, 2009).

The major element systematics of Icelandic basalts provide additional evidence for source heterogeneity (Shorttle and Maclennan, 2011). Specifically, at any given MgO content, ITEenriched magmas are richer in $\mathrm{FeO}_{\mathrm{t}}$ and poorer in $\mathrm{CaO}$ and $\mathrm{SiO}_{2}$ than their ITE-depleted counterparts (Fig. 1b), which probably reflects the presence of recycled basalt in their source 
regions (Shorttle et al., 2014). The CTE contents of olivines reported to date are consistent with the presence of such heterogeneities (Sobolev et al., 2007; Shorttle and Maclennan, 2011; Herzberg et al., 2016).

Analyses of olivine macrocrysts were performed on polished thin sections cut from samples described by Maclennan (2008b): fresh, olivine-rich lava samples collected from Háleyjabunga near $63.8148^{\circ} \mathrm{N}, 22.6516^{\circ} \mathrm{W}$, and glassy pillow lava samples collected from Stapafell near $63.9098^{\circ} \mathrm{N}, 22.5235^{\circ} \mathrm{W}$. Quantitative Estimation of Mineralogy by Scanning Electron Microscopy (QEMSCAN) images of the thin sections (e.g., Neave et al., 2017) reveal that macrocryst assemblages in both eruptions are dominated by olivine alongside minor Cr-spinel and rare plagioclase (Supplementary Material). The few plagioclase crystals we do observe are highly resorbed, indicating that they were out of equilibrium with their carrier melts and are probably xenocrystic in origin. Plagioclase is not considered any further.

Analyses of olivine macrocryst-melt inclusion pairs were also performed on samples from Háleyjabunga. Olivines were obtained by hand crushing samples in a steel mortar and selecting fresh, melt inclusion-bearing grains under a binocular microscope. Melt inclusions in these olivines were re-homogenised for $20 \mathrm{~min}$ in a one atmosphere vertical gas mixing furnace at the Institute for the Study of the Earth's Interior at Okayama University, Japan. Olivines were heated to $1290{ }^{\circ} \mathrm{C}$ based on their likely crystallisation temperature (Maclennan, 2008a) and held at an oxygen fugacity $\left(f_{\mathrm{O}_{2}}\right)$ one log unit below the quartz-fayalite-magnetite buffer (QFM-1) to prevent their oxidation. Although the major element contents of olivinehosted melt inclusions can be severely compromised by interactions with their host olivines during re-homogenisation, ITE systematics are affected much less, meaning that our key findings are robust to the vagaries of inclusion re-homogenisation (Danyushevsky et al., 2000; Jennings et al., 2017).

\section{Analytical methods}

After being inspected optically for signs of alteration and decrepitation, the major and minor element contents of olivine macrocryst cores and olivine-hosted melt inclusions were 
measured by electron probe microanalysis (EPMA) with a Cameca SX100 in the Department of Earth Sciences at the University of Cambridge, UK. Multiple points were analysed across olivine cores to check for heterogeneities in samples that appeared homogeneous during backscattered electron (BSE) imaging. X-ray maps of three olivines were also produced to assess the extent of minor and trace element zoning (e.g., Milman-Barris et al., 2008). Olivine trace element contents were then measured by laser ablation inductively coupled plasma mass spectrometry (LA-ICP-MS) with a ThermoScientific ElementXR fast scanning sector field ICP-MS coupled to a laser ablation system based on a Spectra Physics Solstice $194 \mathrm{~nm}$ femstosecond (fs) laser in the Institute of Mineralogy at the Leibniz Universität Hannover, Germany (e.g., Collinet et al., 2017). Analyses were made using a $30 \mu \mathrm{m}$ laser spot rastered over $100 \times 100 \mu \mathrm{m}$ areas. Signals were monitored for compositional heterogeneities associated with crystal zoning and contamination from melt and Cr-spinel inclusions. Melt inclusion trace element contents were measured by secondary ion mass spectrometry (SIMS) with a Cameca ims-5f in the Institute for the Study of the Earth's Interior at Okayama University, Japan. Further details about analytical methods and standards are provided in Appendix A.

\section{Geochemical systematics of olivines and their melt inclusions}

Olivine macrocrysts from Háleyjabunga are more primitive on average than those from Stapafell (Figs. 3 and 4): almost all olivines from Háleyjabunga have high forsterite cores $\left(\mathrm{Fo}_{89}-\mathrm{Fo}_{91}\right.$, where $\mathrm{Fo}_{0}=100 \times$ atomic $\left.\mathrm{Mg} /\left(\mathrm{Mg}+\mathrm{Fe}^{2+}\right)\right)$, whereas those from Stapafell have somewhat lower forsterite cores $\left(\mathrm{Fo}_{85}-\mathrm{FO}_{88}\right)$. Olivine macrocrysts from the two eruptions can also be distinguished in their minor and trace element contents. For example, while olivine compositions appear to form single arrays on plots of forsterite content plotted against some first row transition elements (FRTEs) (e.g., Mn and Co; Figs. 3e and 3f), they form sub-parallel arrays when plotted against others (e.g., Ni; Fig. 3g). That is, at any given forsterite content, olivines from Stapafell are richer in Ni than those from Háleyjabunga. Distinct compositional groups are also visible in the non-FRTE lithophile element content of olivines: while macrocrysts from Háleyjabunga are generally enriched in Ca with respect 
to those from Stapafell (Figs. 4a and 4b), they are noticeably depleted in ITEs (Zr and Y; Figs. 4c and 4d). Moreover, Ti behaves more similarly to highly incompatible Zr than to the other FRTEs because of its valence-controlled behaviour (Figs. 3b and 4c; Table 1).

Many elements diffuse rapidly through the olivine crystals (Jurewicz and Watson, 1988; Spandler and O'Neill, 2010). While this diffusion can be exploited for chronometric purposes (e.g., Costa et al., 2008), the diffusive re-equilibration of macrocryst compostions can complicate identifying primary geochemical signals (Thomson and Maclennan, 2013; Lynn et al., 2017). However, the sense of correlations between elements that diffuse at different rates suggests that dominant variations observed cannot represent zoning formed by diffusive processes (Appendix B). Furthermore, the extent of zoning observed in X-ray maps implies that intra-grain heterogeneities cannot be responsible for the geochemical variability present across whole populations. Specifically, only one of three grains mapped showed zoning patterns characteristic of rapid olivine crystallisation from enriched boundary layers (Supplementary Material; Milman-Barris et al., 2008; Shea et al., 2015): one macrocryst from Stapafell displays $\mathrm{P}$ and $\mathrm{Al}$ zoning at intensities just above the limit of detection, while two other macrocrysts, one from Háleyjabunga and one from Stapafell, show almost no detectable evidence of internal zoning. Fine-scale trace element zoning thus appears to be neither ubiquitous nor strongly developed in the olivines studied, and may be absent entirely in samples from the Háleyjabunga eruption. Even in a worst case scenario in which all olivines are zoned like the example from Stapafell, the constant $\mathrm{P}$ and $\mathrm{Al}$ count rates observed during LA-ICP-MS analyses indicate that trace element variability within olivine cores is no greater in magnitude than analytical uncertainty (Supplementary Material).

The geochemical characterics of melt inclusions from Háleyjabunga and Stapafell have been discussed in detail by Maclennan (2008b). For the purpose of this study, we summarise the combined major- and trace-element systematics of melt inclusions on plots of host forsterite content versus $\mathrm{Ti} / \mathrm{Y}$ and $\mathrm{Zr} / \mathrm{Y}$ (i.e. Ti/Y $\mathrm{Y}_{\mathrm{MI}}$ and $\mathrm{Zr} / \mathrm{Y}_{\mathrm{MI}}$ ) (Figs. 5a and 5b). These ratios were selected as proxies for ITE enrichment instead of $\mathrm{La} / \mathrm{Yb}$ or $\mathrm{Nb} / \mathrm{Zr}$ because they were determined in both macrocryst and melt inclusion suites. Our new melt inclusion data from Háleyjabunga slightly extend the compositional range reported by Maclennan 
(2008b), but remain ITE-depleted with respect to published data from Stapafell. For example, Ti/Y $\mathrm{Y}_{\mathrm{MI}}$ is 120-400 in inclusions from Háleyjabunga but 350-600 in inclusions from Stapafell. $\mathrm{Zr} / \mathrm{Y}_{\mathrm{MI}}$ values also show an offset (mostly 0.2-3.0 in Háleyjabunga versus 3.05.5 in Stapafell), though rare highly enriched inclusions $\left(\mathrm{Zr} / \mathrm{Y}_{\mathrm{MI}}>3.0\right)$ are also present in the otherwise depleted Háleyjabunga dataset. These highly enriched melt inclusions are texturally indistinguishable from their more depleted counterparts, indicating that they are primary also in origin. Indeed, the injection of small quantities of enriched melt into otherwise depleted reservoirs is well documented in Icelandic systems (Maclennan, 2008a; Neave et al., 2014).

\section{The effect of fractional crystallisation on olivine compositions}

Few oceanic basalts approach the compositions expected for primary melts because they undergo extensive crystallisation at depth (O'Hara, 1968). The effects of shallow differentiation must hence be evaluated before interpreting mineral and melt compositions in terms of mantle-derived variability (Langmuir et al., 1992). In order to determine the effects of crystallisation on the geochemical systematics of our samples, we calculated fractionation paths using a forward modelling approach. Liquid and olivine lines of descent were generated for each eruption by incrementally adding equilibrium olivine compositions to their respective matrix glass compositions. Importantly, our assumption of olivine-only crystallisation is supported both petrographically $\left(>\mathrm{Fo}_{80}\right.$ olivine and $\mathrm{Cr}$-spinel occur in an average ratio of 54:1 in QEMSCAN images of our samples; Supplementary Material) and by observations that olivine and Cr-spinel typically crystallise from primitive melts in cotectic ratios of 100:1 (Roeder et al., 2006).

Matrix glass major element contents were taken from Gurenko and Chaussidon (1995) for Háleyjabunga, and Condomines et al. (1983) and Peate et al. (2009) for Stapafell. Matrix glass trace element contents were estimated from whole-rock compositions using a regression approach described in Appendix C. Equilibrium olivine major element con-

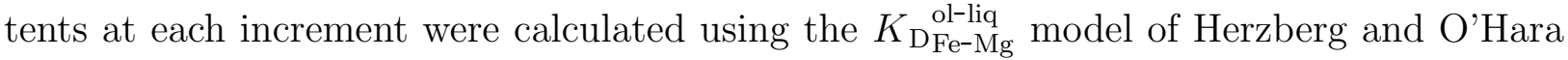
(2002). Matrix glass $\mathrm{Fe}^{3+} / \Sigma \mathrm{Fe}$ values of 0.14 and 0.21 for Háleyjabunga and Stapafell re- 
spectively were estimated using the combined $\mathrm{MgO}-\mathrm{ITE}-\mathrm{Fe}^{3+} / \Sigma \mathrm{Fe}$ systematics of glasses from the nearby Reykjanes Ridge (Shorttle et al., 2015), and the ability of resulting olivine lines of descent to reproduce measured olivine compositions, especially with respect to $f_{\mathrm{O}_{2}}{ }^{-}$ sensitive $\mathrm{V}$. Where possible, olivine minor and trace element contents were estimated using composition-dependent $D^{\text {ol-liq }}$ values (Beattie et al., 1991; Canil, 1997; Herzberg and O'Hara, 2002; Herzberg et al., 2016); $D^{\text {ol-liq }}$ values were otherwise selected from within experimentally determined ranges (Beattie, 1994; Kohn and Schofield, 1994; Gaetani and Grove, 1997; Mallmann and O'Neill, 2009; Spandler and O'Neill, 2010). $D^{\text {ol-liq }}$ values and sources are listed in Table 1. Crystallisation calculations were terminated when modelled forsterite contents reached the most primitive values measured in the products of each eruption. In order to propagate uncertainties in matrix glass compositions into fractionation paths, plausible compositional ranges were determined by re-sampling the regression coefficients used to estimate matrix glass compositions to normal distributions defined by their means and $1 \sigma$ errors (see Appendix C). We thus present fractionation paths as mean values bracketed by coloured fields reflecting their standard errors (Figs. 3, 4 and 5).

The ability of fractional crystallisation to explain the forsterite content-trace element systematics of olivine macrocrysts varies both between the two eruptions and as a function of trace element compatibility, modelled using literature data in the case of the latter (Table 1). For example, $\mathrm{Co}$ and $\mathrm{Ni}$, which are both compatible in olivine, are broadly accounted for by fractional crystallisation, uncertainties in matrix glass compositions notwithstanding (Figs. 3f and 3g): olivine-only fractionation trends are parallel to olivine data arrays. Note, however, that significant changes in $D_{\mathrm{Co}}^{\mathrm{ol}-l i q}$ values during differentiation result in trends that could initially be interpreted as reflecting incompatible behaviour (Fig. 3f). Manganese, which has a $D^{\text {ol-liq }}$ value close to unity, is also largely consistent with fractional crystallisation (Figs. 3e). Vanadium systematics can be broadly reproduced using $D_{\mathrm{V}}^{\mathrm{ol}-l i q}$ values calculated with the $f_{\mathrm{O}_{2}}$-dependent model of Canil (1997) by assuming that the offset in olivine $\mathrm{V}$ contents between Háleyjabunga and Stapafell represents a change in $f_{\mathrm{O}_{2}}$ from QFM+0.3 to QFM+1.1, an assumption consistent with whole-rock ITE systematics (Shorttle et al., 2015). 
While Sc, Ti, Zr and Y, which range from being moderately to highly incompatible in olivine, have compositional arrays that are broadly parallel to fractionation paths calculated for Stapafell, they are either oblique to the paths calculated for Háleyjabunga, or cut across them entirely (Figs. 3a, 3b, 4c and 4d). Al and Ca systematics can be reproduced to a certain degree by our crystallisation models (Figs. 4a and 4b), though $\mathrm{Al}$ is more variable than predicted from crystallisation alone, and $\mathrm{Ca}$ appears depleted in the most evolved olivines from Háleyjabunga. This depletion probably reflects these olivines' growth from a locally plagioclase-saturated melt lens (perhaps reflected by the presence of rare plagioclase crystals). However, Cr systematics are inconsistent with olivine-only fractionation; sharp decreases in olivine $\mathrm{Cr}$ content with decreasing forsterite content are consistent with the co-crystallisation of minor Cr-spinel that had no effect on the systematics of other elements (Appendix D).

ITE ratios are often more illustrative of primary enrichment than ITE concentrations because crystallisation effects are largely cancelled out. For example, melt inclusions from Háleyjabunga and Stapafell are readily discriminated based on their $\mathrm{Ti} / \mathrm{Y}_{\mathrm{MI}}$ and $\mathrm{Zr} / \mathrm{Y}_{\mathrm{MI}}$ contents (Figs. 5a and 5b). Similar offsets between the two eruptions are also observed in olivine macrocryst compositions: $\mathrm{Ti} / \mathrm{Y}_{\mathrm{ol}}$ and $\mathrm{Zr} / \mathrm{Y}_{\mathrm{ol}}$ are elevated in macrocrysts from Stapafell with respect to those from Háleyjabunga (Figs. 5c and 5d). Moreover, Ti/YMI and $\mathrm{Zr} / \mathrm{Y}_{\mathrm{MI}}$ ranges converted into equilibrium olivine compositions largely overlap with compositions determined from olivines themselves ( $D^{\text {ol-liq }}$ values listed in Table 1$)$. Inclusions correspond particularly closely to their hosts in the case of Ti/Y (Fig. 5c), for which the average compositional difference between the two eruptions is also reproduced well by fractional crystallisation calculations. Although $\mathrm{Zr} / \mathrm{Y}_{\mathrm{ol}}$ and $\mathrm{Zr} / \mathrm{Y}_{\mathrm{MI}}$ values from Stapafell broadly align with calculated fractionation paths, $\mathrm{Zr} / \mathrm{Y}_{\mathrm{ol}}$ values from Háleyjabunga are systematically more enriched than both the centroid of $\mathrm{Zr} / \mathrm{Y}_{\mathrm{MI}}$ values and the fractionation paths estimated for this eruption (Fig. 5d). However, this discrepancy is probably analytical in origin: approximately half of the $\mathrm{Zr}$ analyses in olivine macrocrysts from Háleyjabunga were below the detection limit $(<10 \mathrm{ppb})$, leading to an inflation in apparent $\mathrm{Zr}_{\mathrm{ol}}$ concentrations and a reduction in apparent $\mathrm{Zr} / \mathrm{Y}_{\mathrm{ol}}$ variance. It is nevertheless clear that the ITE 
variability evident in whole-rock, matrix glass and melt inclusion samples from Háleyjabunga and Stapafell also manifests in olivine macrocrysts; olivines record inter-eruption variations in ITE enrichment directly.

\section{Correlations between olivine hosts and their melt inclusions}

In order to test whether olivines from Háleyjabunga preserve a similar record of trace element variability to their melt inclusions, we compared the ITE contents of inclusionhost pairs measured in the same crystals (Fig. 6). We found that $\mathrm{Y}_{\mathrm{MI}}$ correlates with $\mathrm{Y}_{\mathrm{ol}}$ $\left(r=0.54\right.$; Figs. 6a), and that $\mathrm{Ti} / \mathrm{Y}_{\mathrm{MI}}$ and $\mathrm{Zr} / \mathrm{Y}_{\mathrm{MI}}$ also correlate with $\mathrm{Ti} / \mathrm{Y}_{\mathrm{ol}}$ and $\mathrm{Zr} / \mathrm{Y}_{\mathrm{ol}}$ respectively $(r=0.60$ and $r=0.49$; Figs. $6 \mathrm{~b}$ and $6 \mathrm{c})$. The null hypothesis that correlations resulted from random noise (i.e. from analytical errors rather than from geological processes) could be rejected at $p<0.01$ in all cases.

Although these correlations between olivine and melt inclusion indicators of ITE enrichment are modest in strength, their presence has two self-reinforcing implications. Firstly, they indicate that enrichments in host crystals and their melt inclusions share a common origin, and hence that neither diffusive pile-up nor dissolution-reaction-mixing processes could have been responsible for the generation of ITE-rich inclusions (cf., Danyushevsky et al., 2004; Baker, 2008). This is because macrocrysts equilibrate with far larger volumes of liquid than their melt inclusions, making them less susceptible to preserving anomalous compositions (see Faure and Schiano (2005) for a discussion about melt inclusion entrapment). ITEenriched melt pools in the Háleyjabunga plumbing system were thus sufficiently voluminous to crystallise large, homogeneous macrocrysts; enrichment was unlikely to have been restricted to the grain or sub-grain scale. Indeed, X-ray maps of an olivine from Háleyjabunga do not show $\mathrm{P}$ zoning patterns characteristic of boundary-layer crystallisation (Supplementary Material; Milman-Barris et al., 2008; Shea et al., 2015). Moreover, given that trace element count rates remained broadly constant during LA-ICP-MS analyses (Supplementary Material), it is unlikely that Háleyjabunga olivines grew from geochemically anomalous boundary layers. 
Secondly, ITE correlations between melt inclusions and their host crystals enable otherwise disparate geochemical characteristics to be integrated. For example, on both intra- and inter-eruption scales, it is likely that ITE-enriched olivines crystallised from different batches of not only elementally but also isotopically enriched melts (Fig. 2b; Maclennan, 2008b). Therefore, ITE enrichment in olivines from the Reykjanes Peninsula plausibly correlates with isotopic enrichment in the mantle source. Moreover, if melt inclusion ITE contents correlate with the ITE contents of their olivine hosts, host olivine CTE systematics can be related directly to indicators of ITE enrichment. For instance, the relative enrichment of $\mathrm{Ni}$ and $\mathrm{Zn}$ in olivines from the Stapafell eruption - Ni and Zn are more abundant at any given forsterite content in olivines from the Stapafell eruption than from the Háleyjabunga eruption - is coupled to an on average ITE-enriched magma composition.

In summary, our observations suggest that variably enriched melt inclusions faithfully reflect the supply of compositionally distinct and volumetrically appreciable mantle melt batches that all contributed significantly to erupted crystal cargoes. Elemental systematics and crystallisation models qualitatively suggest that while olivine CTE contents record primarily crustal differentiation processes, olivine and inclusion ITE contents can preserve signals of mantle-derived variability on both intra- and inter-eruption scales. However, investigating the causes of compositional variability using elemental concentrations and ratios alone excludes the information encoded in the variance structures of geochemical datasets (Rubin and Sinton, 2007; Shorttle, 2015). We therefore demonstrate below how specifically examining variance can help us to understand the causes of geochemical variability in the following section.

\section{Evaluating the origins of trace element variability}

In the previous sections we showed that CTE and ITE variability in Háleyjabunga and Stapafell olivines and their melt inclusions can be accounted for by a mixture of differentiation and primary chemical variability. Here we formally assess whether the chemical variability in our olivine and melt inclusion datasets is more consistent with fractional melting of the mantle or fractional crystallisation at shallower levels. We perform this analysis 
by comparing our olivine and melt inclusion datasets with simple analytical forward models designed to estimate the variance generated by these different processes.

\subsection{Analytical forward models: mathematical background}

Rudge et al. (2013) provided expressions for the moments of a simple and widely used instantaneous fractional melting model described by

$$
c=\frac{C_{0}}{D}(1-X)^{1 / D-1},
$$

where $c$ is the concentration of an element of interest in the liquid, $C_{0}$ is the concentration of the element in the solid source, $D$ is a bulk solid-liquid partition coefficient (which is constant in this case) and $X$ is the degree of melting (e.g., Rollinson, 2014). For our calculations, we used a depleted mantle composition from McKenzie and O'Nions (1991), and calculated bulk $D$ values using mineral modes from Walter (1998) and mineral-liquid partition coefficients taken primarily from McKenzie and O'Nions (1991), with additional FRTE partition coefficients appropriate for modelling high-temperature mafic systems collated from a range of other sources (Klöck and Palme, 1988; Yurimoto and Ohtani, 1992; Horn et al., 1994; Klemme et al., 2006; Righter et al., 2006; Elkins et al., 2008; Liu et al., 2014). Assuming constant weights for each melt increment (i.e. the simplest case of a one-dimensional melting column with constant productivity) and that no mixing or melt accumulation takes place during transport to the crust (e.g., Spiegelman and Kelemen, 2003), the mean compositions and relative variances $\left(\sigma^{2}\right)$ of the resulting melts are described by

$$
\bar{C}_{\text {melt }}=\frac{C_{0}}{X_{\max }}\left(1-\left(1-X_{\max }\right)^{1 / D}\right)
$$

and

$$
\left(\frac{\sigma_{\text {melt }}}{C_{0}}\right)^{2}=\frac{1}{X_{\max }}\left(\frac{1-\left(1-X_{\max }\right)^{2 / D-1}}{D(2-D)}-\frac{\left(1-\left(1-X_{\max }\right)^{1 / D}\right)^{2}}{X_{\max }}\right) .
$$

For interrogating natural data it is convenient to calculate the relative variance with respect to the mean concentration, $\bar{C}_{\text {melt }}$, rather than the unknown source composition, $C_{0}$. Combining 2 and 3 gives the mean-relative variance 


$$
\left(\frac{\sigma_{\text {melt }}}{\bar{C}_{\text {melt }}}\right)^{2}=\frac{X_{\max }\left(1-\left(1-X_{\max }\right)^{(2 / D)-1}\right)}{D(2-D)\left(1-\left(1-X_{\max }\right)^{1 / D}\right)^{2}}-1 .
$$

We also derived the equivalent expressions for fractional crystallisation described by the Rayleigh fractionation equation

$$
c=C_{0} X^{D-1},
$$

where $X$ is now the melt fraction remaining (i.e. $X=1$ is un-differentiated), and $C_{0}$ is the starting liquid composition. The $D$ values we use for fractional crystallisation assume olivine-only differentiation and were calculated for a fixed olivine composition of Fogo. For fractional crystallisation, the mean compositions and relative variances of the melts are thus given by

$$
\begin{gathered}
\bar{C}_{\mathrm{diff}}=\frac{C_{0}}{D} \frac{\left(X_{\min }^{D}-1\right)}{\left(X_{\min }-1\right)}, \\
\left(\frac{\sigma_{\mathrm{diff}}}{C_{0}}\right)^{2}=\frac{1}{X_{\min }-1}\left(\frac{X_{\min }^{2 D-1}-1}{2 D-1}-\frac{1}{D^{2}} \frac{\left(X_{\min }^{D}-1\right)^{2}}{X_{\min }-1}\right),
\end{gathered}
$$

and

$$
\left(\frac{\sigma_{\mathrm{diff}}}{\bar{C}_{\mathrm{diff}}}\right)^{2}=\frac{D^{2}\left(X_{\max }-1\right)\left(X_{\max }^{2 D-1}-1\right)}{\left(X_{\max }^{D}-1\right)^{2}(2 D-1)}-1 .
$$

The initial variance predicted from melting or differentiation (Equations 8 and 4 respectively) can be subsequently reduced by mixing according to

$$
\sigma_{m}^{2}=\sigma_{0}^{2}(1-M)
$$

where $\sigma_{0}^{2}$ is the initial trace element variance, $\sigma_{m}^{2}$ is the resulting trace element variance and $M$ is the mixing parameter $(0 \leq M \leq 1$; Maclennan, 2008a). Mixing therefore complicates our ability to compare observed and predicted trace element variances by reducing the compositional variability present in natural datasets from that originally generated by either melting or crystallisation. However, mixing reduces the variance of trace elements equally 
(i.e. trace elements behave like passive tracers), and so considering the ratio of variances mitigates the effect of mixing on the analysis. (Mixing does nonetheless move all elemental variances closer to the limit of analytical precision, thus hampering analysis of variance ratios in this way.) We consider both raw relative variances (i.e. mean normalised variances) and relative variance ratios in our following comparison of natural data and forward models.

\subsection{Comparison of natural data with analytical variance models}

Relative variances of olivine macrocryst and melt inclusion trace element concentrations were corrected for contributions from analytical errors using the approach of Maclennan et al. (2001), and are compared with analytical forward models of fractional crystallisation, spinelfield melting and garnet-field melting in Figs. 7a, 7b and 7c respectively. Patterns of FRTE variance in olivines from both eruptions can be reproduced by fractional crystallisation when $D^{\text {ol-liq }}$ values are well known and greater than or close to unity (Fig. 7a); variability in olivine $\mathrm{Ni}$, Co and Mn contents can be accounted for by crustal differentiation. Unfortunately, similar comparisons are equivocal on the origins of FRTE variance when partition coefficients are either poorly defined (e.g., Zn and $\mathrm{Cu}$ ) or affected by other factors (e.g., $f_{\mathrm{O}_{2}}$ in the case of V; Canil, 1997), or when an assumption of olivine-only crystallisation is inadequate (e.g., as a result of Cr-spinel crystallisation in the case of Cr; Appendix D).

Differences between the ITE variance structures of Háleyjabunga olivines and melt inclusions on one hand and Stapafell olivines on the other are more discriminatory. The relative variance of ITEs increases with decreasing compatibility in both olivines and melt inclusions from Háleyjabunga. Despite relationships between compatibility and variance being well established for matrix glass and melt inclusion suites (e.g., Sobolev and Shimizu, 1993; Maclennan et al., 2003; Rubin and Sinton, 2007; Shorttle, 2015), comparable records from volcanic macrocryst suites are rare (Winpenny and Maclennan, 2011). Although the nearly three orders of magnitude increase in relative variance across the melt inclusion dataset is more striking than the one order of magnitude increase across the olivine dataset, a steady increase in variance in the order $\mathrm{Sc}-\mathrm{Yb}-\mathrm{Y}-\mathrm{Ti}-\mathrm{Zr}$ indicates that variance and compatibility are related in a way that would be expected for diverse basaltic magmas derived by frac- 
tional melting. Importantly, the ITE variance structures in the Háleyjabunga datasets are inconsistent with a fractional crystallisation origin (Fig. 7a): ITEs cannot be fractionated from each other significantly during differentiation at high melt fractions (i.e. when $X$ is close to 1 , which it must be for melts crystallising such forsteritic olivines). A correlation between ITE variance and incompatibility is however consistent with fractional melting that operates at low melt fractions (i.e. when $X$ is close to 0), implying that ITE variability in Háleyjabunga has been inherited from mantle processes (Figs. 7b and 7c).

In contrast with Háleyjabunga, ITE variance in olivines from Stapafell does not correlate with compatibility: Zr and Y are equally variable, as are Ti and Yb (Fig. 7). The variancecompatibility trend observed for olivines from Stapafell thus cuts across the trends calculated using analytical fractional melting models (Figs. 7b and 7c), meaning that any initial compositional heterogeneities must have been thoroughly overprinted. Broadly constant relative variances in the order $\mathrm{Sc}-\mathrm{Yb}-\mathrm{Y}-\mathrm{Ti}-\mathrm{Zr}$ are however consistent with fractional crystallisation being the dominant control on trace element variance in olivines from Stapafell (Fig. 7a). In order to validate the dichotomy between melting-dominated signals in Háleyjabunga and crystallisation-dominated signals in Stapafell, we now extend our analysis to relative variance ratios (e.g., $\sigma_{\mathrm{Zr}}^{2} / \sigma_{\mathrm{Y}}^{2}$ ) that are more robust to degradation by mixing.

Observed relative variance ratios are compared with relative variance ratios calculated for fractional crystallisation and fractional melting in Figs. 8a and 8b respectively. In line with observations from raw relative variances, $\sigma_{\mathrm{Zr}}^{2} / \sigma_{\mathrm{Y}}^{2}$ for the olivine dataset from Stapafell is reproduced better by fractional crystallisation than partial melting (Fig 8a). Moreover, although spinel-field melting can also reproduce the observed variance, garnet-field melting, which is required to generate observed REE patterns (Gurenko and Chaussidon, 1995), would result in much more variance than observed. Our analysis of trace element variance in olivine macrocrysts from Stapafell is thus wholly consistent with previous interpretations that any mantle-derived heterogeneity in the Stapafell magma must have been erased by mixing before crystallisation took place (Maclennan, 2008b). Indeed, numerical treatments of basalt mixing suggest that ITE-enriched magmas like those erupted at Stapafell may be homogenised during their extraction from the mantle, reducing the variability of ITE- 
enriched melts before they even reach the crust (Rudge et al., 2013; Jennings et al., 2017).

Fractional crystallisation cannot reproduce the relative variance ratios observed in either olivine macrocrysts or melt inclusions from Háleyjabunga (Fig. 8a). Fractional melting in the garnet-field is nevertheless capable of generating the variance observed in the olivine dataset, though it underestimates the amount of variability in the melt inclusion dataset. However, we do not attach any geological significance to this mismatch for the following two reasons: firstly, $\sigma_{\mathrm{Zr}}^{2}$ is probably underestimated because $\mathrm{Zr}$ was present at below-detectionlimit levels in the most ITE-depleted macrocrysts; and secondly, our treatment of mantle melting is highly simplified and useful only in an illustrative sense - robust treatments of mantle melting must not only take account of the pressure-temperature-composition dependence of partition coefficients (Blundy and Wood, 2003), but also the variable fusibilities of different components in a geochemically and lithologically heterogeneous mantle (Hirschmann and Stolper, 1996; Shorttle et al., 2014). Nevertheless, it seems beyond doubt that mantle melting is responsible for generating the ITE variance in the Háleyjabunga eruption, and that this has been recorded in both olivine and olivine-hosted melt inclusion compositions.

\section{Enriched lithologies in the Icelandic mantle}

Differences between average ITE concentrations and ratios in samples from Háleyjabunga and Stapafell reflect different mantle melting conditions (Fig. 7; Gurenko and Chaussidon, 1995). Furthermore, differences in isotopic composition between the two eruptions imply that source heterogeneity also contributed towards their distinctive chemistries (Maclennan, 2008b). However, neither ITEs nor radiogenic isotopes encode much information about variations in mantle lithology; only the former encode information about the presence of spinel or garnet in the mantle source. In contrast, FRTEs, which range from being highly compatible to moderately incompatible in mantle minerals (e.g., Le Roux et al., 2011), are theoretically much more sensitive to variations in source lithology, and high $\mathrm{Ni} /(\mathrm{Mg} / \mathrm{Fe})$, $\mathrm{Fe} / \mathrm{Mn}, \mathrm{Ni} / \mathrm{Co}$ and 10000Zn/Fe values have all been proposed as proxies for olivine-free 
lithologies in the source regions of enriched OIBs (Sobolev et al., 2007; Le Roux et al., 2010; Herzberg et al., 2016).

Although olivines from Stapafell are Ni-rich with respect to those from Háleyjabunga (Fig. 3g), olivine $\mathrm{Ni} /(\mathrm{Mg} / \mathrm{Fe})$ contents from both eruptions $(756 \pm 59(1 \sigma)$ and $625 \pm 34(1 \sigma)$ respectively) lie firmly within the peridotitic source field defined by Sobolev et al. (2007). Olivines from the two eruptions are also barely distinguishable in terms of their Fe/Mn and 10000Zn/Fe contents $(65.6 \pm 3.0(1 \sigma)$ and 8.3 $\pm 1.1(1 \sigma)$, and $61.6 \pm 2.1(1 \sigma)$ and $8.9 \pm 0.4(1 \sigma)$ in olivines from Stapafell and Háleyjabunga respectively). Olivine CTE contents from these geochemical end-member eruptions thus imply melting of an isotopically heterogeneous yet lithologically homogeneous mantle source. Moreover, the higher Ni content of olivines from Stapafell can be accounted for by the large temperature difference between the source regions of ITE-enriched melts and the crust where they start to crystallise (Matzen et al., 2013; Matthews et al., 2016). However, the Fe and Ca systematics of Icelandic basalts, including of those from the Reykjanes Peninsula, are inconsistent with a single mantle source lithology (Shorttle and Maclennan, 2011). A more nuanced interpretation is thus required.

By identifying correlations between trace and major elements in primitive basalts from Iceland, Shorttle and Maclennan (2011) demonstrated that the high Fe content of ITEenriched magmas cannot be generated by melting KLB1-like lherzolite alone, an interpretation supported by recent thermodymanic investigations of mantle melting (Jennings et al., 2016). Shorttle and Maclennan (2011) hence concluded that an enriched and more fusible component is also required to match combined geochemical and geophysical (e.g., crustal thickness) observations from Iceland. Shorttle et al. (2014) subsequently developed a tri-lithologic (i.e. lherzolite-harzburgite-pyroxenite (sensu lato)) melting model that best reproduced geological observations from Iceland when $10 \%$ of the mantle was composed of enriched, pyroxenitic material. Importantly, similar results were obtained when either an olivine-free pyroxenite (G2; Pertermann and Hirschmann, 2003) or an olivine-bearing pyroxenite-peridotite hybrid (KG1; Kogiso et al., 1998) were considered as potential enriched lithologies.

Integrating our CTE measurements, which are indicative of a peridotitic mantle source, 
with the observations and modelling of Shorttle and Maclennan (2011) and Shorttle et al. (2014), which necessitate lithological heterogeneity, suggests that enriched magmas from the Reykjanes Peninsula of Iceland are sourced from lithologically enriched yet still olivinebearing mantle domains (cf., Sobolev et al., 2007). Crucially, even if olivine-free pyroxenites were present in the Icelandic mantle, the CTE content of the ITE-enriched olivines we have observed severely limits their possible contribution to aggregated melts: we observe olivine CTE contents to be overwhelmingly dominated by melts from olivine-bearing lithologies.

The implications of this synthesis are two-fold. Firstly, the subducted material that ultimately formed enriched components of the Icelandic mantle is unlikely to have retained physical coherency during subsequent mixing and reaction with more depleted components (e.g., Gurenko et al., 2009). Indeed, enriched lithologies sampled by melting are thought to be generated in myriad ways (Herzberg, 2011). Secondly, observing olivine CTE systematics indicative of melt supply from olivine-bearing lithologies is insufficent evidence to discount lithological heterogeneity in the source regions of their carrier melts. That is, olivine FRTE contents from the Reykjanes Peninsula are insensitive to the modal heterogeneity required to account for the major element contents of their host lavas. Thus, the presence and abundance of enriched mantle lithologies cannot be simply estimated from the minor element content of erupted olivines as previously envisaged (e.g., Sobolev et al., 2007; Le Roux et al., 2011).

\section{Summary}

We have used microanalytical observations of olivine macrocrysts and melt inclusions from two primitive and variably enriched eruptions from Iceland to demonstrate that inclusions and their host crystals preserve coherent patterns of trace element variability and hence record the same magmatic processes. We show that degrees of mantle-derived ITE enrichment can be estimated from olivine macrocrysts directly, albeit with a greater uncertainty than when using melt inclusion compositions, and only if olivine macrocryst compositions have not been compromised by rapid growth under disequilibrium conditions. Formerly inaccessible records of geochemical variability preserved in olivine macrocrysts from ancient or altered samples are thus now within analytical grasp. Moreover, by measuring the ITE 
content of olivine macrocrysts alongside their CTE contents, we have been able to integrate previously decoupled ITE and CTE records of melting and crystallisation processes.

Simple fractional crystallisation models reveal that much intra-eruption CTE variability (concentrations and variance) in our Icelandic samples can be accounted for by magmatic differentiation in the crust, i.e. by olivine crystallisation. Although ITE variability (concentrations, ratios and variance) in the enriched Stapafell eruption is also consistent with fractional crystallisation, ITE variability in the depleted Háleyjabunga eruption has been largely inherited from mantle melting. Importantly, inter- and intra-eruption correlations between olivine and inclusion ITE contents validates previous assumptions that olivinehosted melt inclusions are reliable archives of mantle-derived heterogeneity; localised crustal processes are unlikely to generate the majority of ITE-enriched melt inclusions.

By integrating our CTE and ITE data with previously published major element data and modelling studies, we conclude that there is currently no evidence for the presence of olivine-free lithologies in the Icelandic mantle. Our findings are instead consistent with a mantle source containing $\sim 10 \%$ modally enriched peridotite, a fusible and Fe-rich lithology that can simultaneously account for the olivine chemistry we observe and the combined major and trace element systematics of Icelandic basalts documented more widely. We thus show that olivine CTE contents provide an incomplete picture of lithological heterogeneity in the mantle, and must be combined with other observations to accurately estimate proportions of enriched or recycled components at depth. Modally enriched, but olivine-bearing, mantle domains may therefore contribute more significantly to the genesis of oceanic magmas in a range of settings than previously inferred from the CTE content of erupted olivine macrocrysts.

\section{Acknowledgements}

DAN was supported by an Alexander von Humboldt Postdoctoral Research Fellowship. OS was supported in Cambridge by a Title A Fellowship from Trinity College, and in Japan by a JSPS Postdoctoral Fellowship and Furusato Award. We thank Renat Almeev and Chao Zhang, and Iris Buisman for their help with EPMA in Hannover and Cambridge respectively. 
We also thank two anonymous reviewers for their detailed comments and Tamsin Mather for her further comments and efficient editorial handling.

\section{References}

Baker, D. R., 2008. The fidelity of melt inclusions as records of melt composition. Contributions to Mineralogy and Petrology 156 (3), 377-395.

Beattie, P., 1994. Systematics and energetics of trace-element partitioning between olivine and silicate melts: Implications for the nature of mineral/melt partitioning. Chemical Geology 117 (1-4), 57-71.

Beattie, P., Ford, C., Russell, D., 1991. Partition coefficients for olivine-melt and orthopyroxene-melt systems. Contributions to Mineralogy and Petrology 109 (2), 212-224.

Blundy, J. D., Wood, B. J., 2003. Partitioning of trace elements between crystals and melts. Earth and Planetary Science Letters 210 (3-4), 383-397.

Canil, D., 1997. Vanadium partitioning and the oxidation state of Archaean komatiite magmas. Nature 389, $842-845$.

Cherniak, D. J., Liang, Y., 2014. Titanium diffusion in olivine. Geochimica et Cosmochimica Acta 147, $43-57$.

Collinet, M., Charlier, B., Namur, O., Oeser, M., Médard, E., Weyer, S., 2017. Crystallization history of enriched shergottites from $\mathrm{Fe}$ and $\mathrm{Mg}$ isotope fractionation in olivine megacrysts. Geochimica et Cosmochimica Acta 207, 277-297.

Condomines, M., Grönvold, K., Hooker, P. J., Muehlenbachs, K., O’Nions, R. K., Óskarsson, N., Oxburgh, E. R., 1983. Helium, oxygen, strontium and neodymium isotopic relationships in Icelandic volcanics. Earth and Planetary Science Letters 66, 125-136.

Coogan, L. A., Hain, A., Stahl, S., Chakraborty, S., 2005. Experimental determination of the diffusion coefficient for calcium in olivine between $900^{\circ} \mathrm{C}$ and $1500^{\circ} \mathrm{C}$. Geochimica et Cosmochimica Acta 69 (14), 3683-3694.

Costa, F., Dohmen, R., Chakraborty, S., 2008. Time scales of magmatic processes from modeling the zoning patterns of crystals. Reviews in Mineralogy and Geochemistry 69, 545-59.

Costa, F., Morgan, D. J., 2010. Time constraints from chemical equilibration in magmatic crystals. In: Turner, S. P., van Orman, J. A. (Eds.), Timescales of magmatic processes: From core to atmosphere. Blackwell, Oxford, Ch. 7, pp. 125-159.

Danyushevsky, L. V., Della-Pasqua, F. N., Sokolov, S., 2000. Re-equilibration of melt inclusions trapped by magnesian olivine phenocrysts from subduction-related magmas: petrological implications. Contributions to Mineralogy and Petrology 138 (1), 68-83.

Danyushevsky, L. V., Leslie, R. A. J., Crawford, A. J., Durance, P., 2004. Melt inclusions in primitive olivine 
phenocrysts: The role of localized reaction processes in the origin of anomalous compositions. Journal of Petrology 45 (12), 2531-2553.

Davidson, J. P., Tepley, F. J., 1997. Recharge in volcanic systems: Evidence from isotope profiles of phenocrysts. Science 275 (5301), 826-829.

Dohmen, R., Becker, H.-W., Chakraborty, S., 2007. Fe-Mg diffusion in olivine I: Experimental determination between 700 and $1,200{ }^{\circ} \mathrm{C}$ as a function of composition, crystal orientation and oxygen fugacity. Physics and Chemistry of Minerals 34 (6), 389-407.

Dupré, B., Allègre, C. J., 1983. Pb-Sr isotope variation in Indian Ocean basalts and mixing phenomena. Nature 303 (5913), 142-146.

Elkins, L. J., Gaetani, G. A., Sims, K. W. W., 2008. Partitioning of U and Th during garnet pyroxenite partial melting: Constraints on the source of alkaline ocean island basalts. Earth and Planetary Science Letters 265 (1-2), 270-286.

Faure, F., Schiano, P., 2005. Experimental investigation of equilibration conditions during forsterite growth and melt inclusion formation. Earth and Planetary Science Letters 236 (3-4), 882-898.

Fitton, J. G., Saunders, A. D., Kempton, P. D., Hardarson, B. S., 2003. Does depleted mantle form an intrinsic part of the Iceland plume? Geochemistry, Geophysics, Geosystems 4 (3), 1-14.

Foley, S. F., Prelevic, D., Rehfeldt, T., Jacob, D. E., 2013. Minor and trace elements in olivines as probes into early igneous and mantle melting processes. Earth and Planetary Science Letters 363, 181-191.

Gaetani, G. A., Grove, T. L., 1997. Partitioning of moderately siderophile elements among olivine, silicate melt, and sulfide melt: Constraints on core formation in the Earth and Mars. Geochimica et Cosmochimica Acta 61 (9), 1829-1846.

Gee, M. A. M., Taylor, R. N., Thirlwall, M. F., Murton, B. J., 1998. Glacioisostacy controls chemical and isotopic characteristics of tholeiites from the Reykjanes Peninsula, SW Iceland. Earth and Planetary Science Letters 164 (1-2), 1-5.

Gurenko, A. A., Chaussidon, M., 1995. Enriched and depleted primitive melts included in olivine from Icelandic tholeiites: Origin by continuous melting of a single mantle column. Geochimica et Cosmochimica Acta 59 (14), 2905-2917.

Gurenko, A. A., Sobolev, A. V., Hoernle, K. A., Hauff, F., Schmincke, H.-U., 2009. Enriched, HIMUtype peridotite and depleted recycled pyroxenite in the Canary plume: A mixed-up mantle. Earth and Planetary Science Letters 277 (3-4), 514-524.

Hardarson, B. S., Fitton, J. G., Ellam, R. M., Pringle, M. S., 1997. Rift relocation A geochemical and geochronological investigation of a palaeo-rift in northwest Iceland. Earth and Planetary Science Letters 153 (3-4), 181-196.

Hémond, C., Arndt, N. T., Lichtenstein, U., Hofmann, A. W., Óskarsson, N., Steinthórsson, S., 1993. The 
heterogeneous Iceland plume: Nd-Sr-O isotopes and trace element constraints. Journal of Geophysical Research 98 (B9), 15833-15850.

Herzberg, C., 2011. Identification of source lithology in the Hawaiian and Canary Islands: Implications for origins. Journal of Petrology 52 (1), 113-146.

Herzberg, C., O'Hara, M. J., 2002. Plume-associated ultramafic magmas of phanerozoic age. Journal of Petrology 43 (10), 1857-1883.

Herzberg, C., Vidito, C., Starkey, N. A., 2016. Nickel-cobalt contents of olivine record origins of mantle peridotite and related rocks. American Mineralogist 101, 1952-1966.

Hirschmann, M. M., Stolper, E. M., 1996. A possible role for garnet pyroxenite in the origin of the 'garnet signature' in MORB. Contributions to Mineralogy and Petrology 124, 185-208.

Horn, I., Foley, S. F., Jackson, S. E., Jenner, G. A., 1994. Experimentally determined partitioning of high field strength and selected transition elements between spinel and basaltic melt. Chemical Geology 117 (14), 193-218.

Horn, I., von Blanckenburg, F., Schoenberg, R., Steinhoefel, G., Markl, G., 2006. In situ iron isotope ratio determination using UV-femtosecond laser ablation with application to hydrothermal ore formation processes. Geochimica et Cosmochimica Acta 70 (14), 3677-3688.

Jakobsson, S. P., Jónsson, J., Shido, F., 1978. Petrology of the western Reykjanes Peninsula, Iceland. Journal of Petrology 19 (4), 669-705.

Jarosewich, E., Nelen, J. A., Norberg, J. A., 1980. Reference samples for electron microprobe analysis. Geostandards Newsletter 4 (1), 43-47.

Jennings, E. S., Gibson, S. A., Maclennan, J., Heinonen, J. S., 2017. Deep mixing of mantle melts beneath continental flood basalt provinces: Constraints from olivine-hosted melt inclusions in primitive magmas. Geochimica et Cosmochimica Acta 196, 36-57.

Jennings, E. S., Holland, T. J. B., Shorttle, O., Maclennan, J., Gibson, S. A., 2016. The composition of melts from a heterogeneous mantle and the origin of ferropicrite: Application of a thermodynamic model. Journal of Petrology 57, 2289-2310.

Jochum, K. P., Stoll, B., Herwig, K., Willbold, M., Hofmann, A. W., Amini, M., Aarburg, S., Abouchami, W., Hellebrand, E., Mocek, B., Raczek, I., Stracke, A., Alard, O., Bouman, C., Becker, S., Dücking, M., Brätz, H., Klemd, R., de Bruin, D., Canil, D., Cornell, D., de Hoog, C. J., Dalpé, C., Danyushevsky, L. V., Eisenhauer, A., Gao, Y., Snow, J. E., Groschopf, N., Günther, D., Latkoczy, C., Guillong, M., Hauri, E. H., Höfer, H. E., Lahaye, Y., Horz, K., Jacob, D. E., Kasemann, S. A., Kent, A. J. R., Ludwig, T., Zack, T., Mason, P. R. D., Meixner, A., Rosner, M., Misawa, K., Nash, B. P., Pfänder, J., Premo, W. R., Sun, W. D., Tiepolo, M., Vannucci, R., Vennemann, T., Wayne, D., Woodhead, J. D., 2006. MPI-DING reference glasses for in situ microanalysis: New reference values for element concentrations 
and isotope ratios. Geochemistry, Geophysics, Geosystems 7 (2), 1-44.

Jochum, K. P., Willbold, M., Raczek, I., Stoll, B., Herwig, K., 2005. Chemical characterisation of the USGS reference glasses GSA-1G, GSC-1G, GSD-1G, GSE-1G, BCR-2G, BHVO-2G and BIR-1G using EPMA, ID-TIMS, ID-ICP-MS and LA-ICP-MS. Geostandards and Geoanalytical Research 29, 285-302.

Jóhannesson, H., Sæmundsson, K., 2009. Geological map of Iceland. 1:600000. Tectonics (2nd ed.). Tech. rep., Icelandic Institute of Natural History, Reykjavik.

Jurewicz, A. J. G., Watson, E. B., 1988. Cations in olivine, Part 2: Diffusion in olivine xenocrysts, with applications to petrology and mineral physics. Contributions to Mineralogy and Petrology 99 (2), 186-201.

Kelemen, P. B., Hirth, G., Shimizu, N., Spiegelman, M., Dick, H. J. B., 1997. A review of melt migration processes in the adiabatically upwelling mantle beneath oceanic spreading ridges. Philosophical Transactions of the Royal Society A: Mathematical, Physical and Engineering Sciences 355 (1723), 283-318.

Klemme, S., Günther, D., Hametner, K., Prowatke, S., Zack, T., 2006. The partitioning of trace elements between ilmenite, ulvospinel, armalcolite and silicate melts with implications for the early differentiation of the moon. Chemical Geology 234 (3-4), 251-263.

Klöck, W., Palme, H., 1988. Partitioning of siderophile and chalcophile elements between sulfide, olivine, and glass in a naturally reduced basalt from Disko Island, Greenland. Lunar and Planetary Science Conference Proceedings 18, 471-483.

Kogiso, T., Hirose, K., Takahashi, E., 1998. Melting experiments on homogeneous mixtures of peridotite and basalt: Application to the genesis of ocean island basalts. Earth and Planetary Science Letters 162 (1-4), $45-61$.

Kohn, S. C., Schofield, P. F., 1994. The importance of melt composition in controlling trace-element behaviour: an experimental study of $\mathrm{Mn}$ and $\mathrm{Zn}$ partitioning between forsterite and silicate melts. Chemical Geology 117 (1-4), 73-87.

Langmuir, C. H., 1989. Geochemical consequences of in situ crystallization. Nature 340 (6230), 199-205.

Langmuir, C. H., Klein, E. M., Plank, T., 1992. Mantle flow and melt generation at mid-ocean ridges. Geophysical Monograph Series 71, 183-280.

Le Roux, V., Dasgupta, R., Lee, C.-T. A., 2011. Mineralogical heterogeneities in the Earth's mantle: Constraints from Mn, Co, Ni and Zn partitioning during partial melting. Earth and Planetary Science Letters 307 (3-4), 395-408.

Le Roux, V., Lee, C.-T. A., Turner, S. J., 2010. Zn/Fe systematics in mafic and ultramafic systems: Implications for detecting major element heterogeneities in the Earth's mantle. Geochimica et Cosmochimica Acta 74 (9), 2779-2796.

Lissenberg, C. J., MacLeod, C. J., 2016. A reactive porous flow control on mid-ocean ridge magmatic evolution. Journal of Petrology 57 (11\&12), 2195-2220. 
Liu, X., Xiong, X., Audétat, A., Li, Y., Song, M., Li, L., Sun, W., Ding, X., 2014. Partitioning of copper between olivine, orthopyroxene, clinopyroxene, spinel, garnet and silicate melts at upper mantle conditions. Geochimica et Cosmochimica Acta 125, 1-22.

Lynn, K. J., Shea, T., Garcia, M. O., 2017. Nickel variability in Hawaiian olivine: Evaluating the relative contributions from mantle. American Mineralogist 102, 507-518.

Maclennan, J., 2008a. Concurrent mixing and cooling of melts under Iceland. Journal of Petrology 49 (11), 1931-1953.

Maclennan, J., 2008b. Lead isotope variability in olivine-hosted melt inclusions from Iceland. Geochimica et Cosmochimica Acta 72 (16), 4159-4176.

Maclennan, J., McKenzie, D., Grönvold, K., 2001. Plume-driven upwelling under Central Iceland. Earth and Planetary Science Letters 194 (1-2), 67-82.

Maclennan, J., McKenzie, D., Grönvold, K., Shimizu, N., Eiler, J. M., Kitchen, N., 2003. Melt mixing and crystallization under Theistareykir, northeast Iceland. Geochemistry, Geophysics, Geosystems 4 (11), $1-40$.

Mallmann, G., O'Neill, H. S. C., 2009. The crystal/melt partitioning of V during mantle melting as a function of oxygen fugacity compared with some other elements (Al, P, Ca, Sc, Ti, Cr, Fe, Ga, Y, Zr and $\mathrm{Nb})$. Journal of Petrology 50 (9), 1765-1794.

Matthews, S., Shorttle, O., Maclennan, J., 2016. The temperature of the Icelandic mantle from olivine-spinel aluminum exchange thermometry. Geochemistry, Geophysics, Geosystems 17 (11), 4725-4752.

Matzen, A. K., Baker, M. B., Beckett, J. R., Stolper, E. M., 2013. The temperature and pressure dependence of nickel partitioning between olivine and silicate melt. Journal of Petrology 54 (12), 2521-2545.

McKenzie, D., O’Nions, R. K., 1991. Partial melt distributions from inversion of rare earth element concentrations. Journal of Petrology 23, 1021-1091.

Michael, P. J., Schilling, J. G., 1989. Chlorine in mid-ocean ridge magmas: Evidence for assimilation of seawater-influenced components. Geochimica et Cosmochimica Acta 53 (12), 3131-3143.

Milman-Barris, M. S., Beckett, J. R., Baker, M. B., Hofmann, A. E., Morgan, Z., Crowley, M. R., Vielzeuf, D., Stolper, E. M., 2008. Zoning of phosphorus in igneous olivine. Contributions to Mineralogy and Petrology 155 (6), 739-765.

Neave, D. A., Buisman, I., Maclennan, J., 2017. Continuous mush disaggregation during the long-lasting Laki fissure eruption, Iceland. American Mineralogist 102, 2007-2021.

Neave, D. A., Maclennan, J., Edmonds, M., Thordarson, T., 2014. Melt mixing causes negative correlation of trace element enrichment and $\mathrm{CO}_{2}$ content prior to an Icelandic eruption. Earth and Planetary Science Letters $400,272-283$.

O’Hara, M. J., 1968. Are ocean floor basalts primary magma? Nature 220, 683-686. 
O'Hara, M. J., 1977. Geochemical evolution during fractional crystallisation of a periodically refilled magma chamber. Nature 266 (5602), 503-507.

O’Neill, H. S. C., Jenner, F. E., 2016. Causes of the compositional variability among ocean floor basalts. Journal of Petrology 57 (11\&12), 2163-2194.

Peate, D. W., Baker, J. A., Jakobsson, S. P., Waight, T. E., Kent, A. J. R., Grassineau, N. V., Skovgaard, A. C., 2009. Historic magmatism on the Reykjanes Peninsula, Iceland: A snap-shot of melt generation at a ridge segment. Contributions to Mineralogy and Petrology 157 (3), 359-382.

Pertermann, M., Hirschmann, M. M., 2003. Partial melting experiments on a MORB-like pyroxenite between 2 and $3 \mathrm{GPa}$ : Constraints on the presence of pyroxenite in basalt source regions from solidus location and melting rate. Journal of Geophysical Research 108, 2125.

Petry, C., Chakraborty, S., Palme, H., 2004. Experimental determination of Ni diffusion coefficients in olivine and their dependence on temperature, composition, oxygen fugacity, and crystallographic orientation. Geochimica et Cosmochimica Acta 68 (20), 4179-4188.

Poustovetov, A., Roeder, P. L., 2001. Numerical modeling of major element distribution between chromian spinel and basaltic melt, with application to chromian spinel in MORBs. Contributions to Mineralogy and Petrology $142(1), 58-71$.

Putirka, K., Ryerson, F. J., Perfit, M., Ridley, W. I., 2011. Mineralogy and composition of the oceanic mantle. Journal of Petrology 52 (2), 279-313.

Qin, Z., Lu, F., Anderson, A. T., 1992. Diffusive reequilibration of melt and fluid inclusions. American Mineralogist 77 (5-6), 565-576.

Righter, K., Leeman, W. P., Hervig, R. L., 2006. Partitioning of Ni, Co and V between spinel-structured oxides and silicate melts: Importance of spinel composition. Chemical Geology 227 (1-2), 1-25.

Roedder, E., 1979. Origin and significance of magmatic inclusions. Bulletin Minéralerogique 102, 487-510.

Roeder, P. L., Gofton, E., Thornber, C., 2006. Cotectic proportions of olivine and spinel in olivine-tholeiitic basalt and evaluation of pre-eruptive processes. Journal of Petrology 47 (5), 883-900.

Rollinson, H., 2014. Using geochemical data: Evaluation, presentation, interpretation, 2nd Edition. Routledge, Abingdon.

Rubin, K. H., Sinton, J. M., 2007. Inferences on mid-ocean ridge thermal and magmatic structure from MORB compositions. Earth and Planetary Science Letters 260 (1-2), 257-276.

Rubin, K. H., Sinton, J. M., Maclennan, J., Hellebrand, E., 2009. Magmatic filtering of mantle compositions at mid-ocean-ridge volcanoes. Nature Geoscience 2 (5), 321-328.

Rudge, J. F., Maclennan, J., Stracke, A., 2013. The geochemical consequences of mixing melts from a heterogeneous mantle. Geochimica et Cosmochimica Acta 114, 112-143.

Shea, T., Lynn, K. J., Garcia, M. O., 2015. Cracking the olivine zoning code: Distinguishing between crystal 
growth and diffusion. Geology 43 (10), 935-938.

Shorttle, O., 2015. Geochemical variability in MORB controlled by concurrent mixing and crystallisation. Earth and Planetary Science Letters 424, 1-14.

Shorttle, O., Maclennan, J., 2011. Compositional trends of Icelandic basalts: Implications for short-length scale lithological heterogeneity in mantle plumes. Geochemistry, Geophysics, Geosystems 12 (11), 1-32.

Shorttle, O., Maclennan, J., Lambart, S., 2014. Quantifying lithological variability in the mantle. Earth and Planetary Science Letters 395, 24-40.

Shorttle, O., Moussallam, Y., Hartley, M. E., Maclennan, J., Edmonds, M., Murton, B. J., 2015. Fe-XANES analyses of Reykjanes Ridge basalts: Implications for oceanic crust's role in the solid Earth oxygen cycle. Earth and Planetary Science Letters 427, 272-285.

Shorttle, O., Rudge, J. F., Maclennan, J., Rubin, K. H., 2016. A statistical description of concurrent mixing and crystallization during MORB differentiation: Implications for trace element enrichment. Journal of Petrology 57 (11\&12), 2127-2162.

Skovgaard, A. C., Storey, M., Baker, J., Blusztajn, J., Hart, S. R., 2001. Osmium-oxygen isotopic evidence for a recycled and strongly depleted component in the Iceland mantle plume. Earth and Planetary Science Letters 194 (1-2), 259-275.

Sobolev, A. V., Hofmann, A. W., Kuzmin, D. V., Yaxley, G. M., Arndt, N. T., Chung, S.-L., Danyushevsky, L. V., Elliott, T., Frey, F. A., Garcia, M. O., Gurenko, A. A., Kamenetsky, V. S., Kerr, A. C., Krivolutskaya, N. A., Matvienkov, V. V., Nikogosian, I. K., Rocholl, A., Sigurdsson, I. A., Sushchevskaya, N. M., Teklay, M., 2007. The amount of recycled crust in sources of mantle-derived melts. Science 316 (5823), $412-417$.

Sobolev, A. V., Hofmann, A. W., Sobolev, S. V., Nikogosian, I. K., 2005. An olivine-free mantle source of Hawaiian shield basalts. Nature 434 (7033), 590-597.

Sobolev, A. V., Shimizu, N., 1993. Ultra-depleted primary melt included in an olivine from the Mid-Atlantic Ridge. Nature 363 (6425), 151-154.

Spandler, C., O'Neill, H. S. C., 2010. Diffusion and partition coefficients of minor and trace elements in San Carlos olivine at $1,300^{\circ} \mathrm{C}$ with some geochemical implications. Contributions to Mineralogy and Petrology 159 (6), 1-28.

Spiegelman, M., Kelemen, P. B., 2003. Extreme chemical variability as a consequence of channelized melt transport. Geochemistry, Geophysics, Geosystems 4 (7).

Stead, C. V., Tomlinson, E. L., Kamber, B. S., Babechuk, M. G., McKenna, C. A., 2016. Rare earth element determination in olivine by laser ablation-quadrupole-ICP-MS: An analytical strategy and applications. Geostandards and Geoanalytical Research 41, 1-16.

Thirlwall, M. F., Gee, M. A. M., Lowry, D., Mattey, D. P., Murton, B. J., Taylor, R. N., 2006. Low $\delta^{18}$ O in 
the Icelandic mantle and its origins: Evidence from Reykjanes Ridge and Icelandic lavas. Geochimica et Cosmochimica Acta 70 (4), 993-1019.

Thirlwall, M. F., Gee, M. A. M., Taylor, R. N., Murton, B. J., 2004. Mantle components in Iceland and adjacent ridges investigated using double-spike $\mathrm{Pb}$ isotope ratios. Geochimica et Cosmochimica Acta 68 (2), 361-386.

Thomson, A., Maclennan, J., 2013. The distribution of olivine compositions in icelandic basalts and picrites. Journal of Petrology 54 (4), 745-768.

Walter, M. J., 1998. Melting of garnet peridotite and the origin of komatiite and depleted lithosphere. Journal of Petrology 39 (1), 29-60.

Winpenny, B., Maclennan, J., 2011. A partial record of mixing of mantle melts preserved in Icelandic phenocrysts. Journal of Petrology 52 (9), 1791-1812.

Yurimoto, H., Ohtani, E., 1992. Element partitioning between majorite and liquid: A secondary ion mass spectrometric study. Geophysical Research Letters 19 (1), 17-20. 

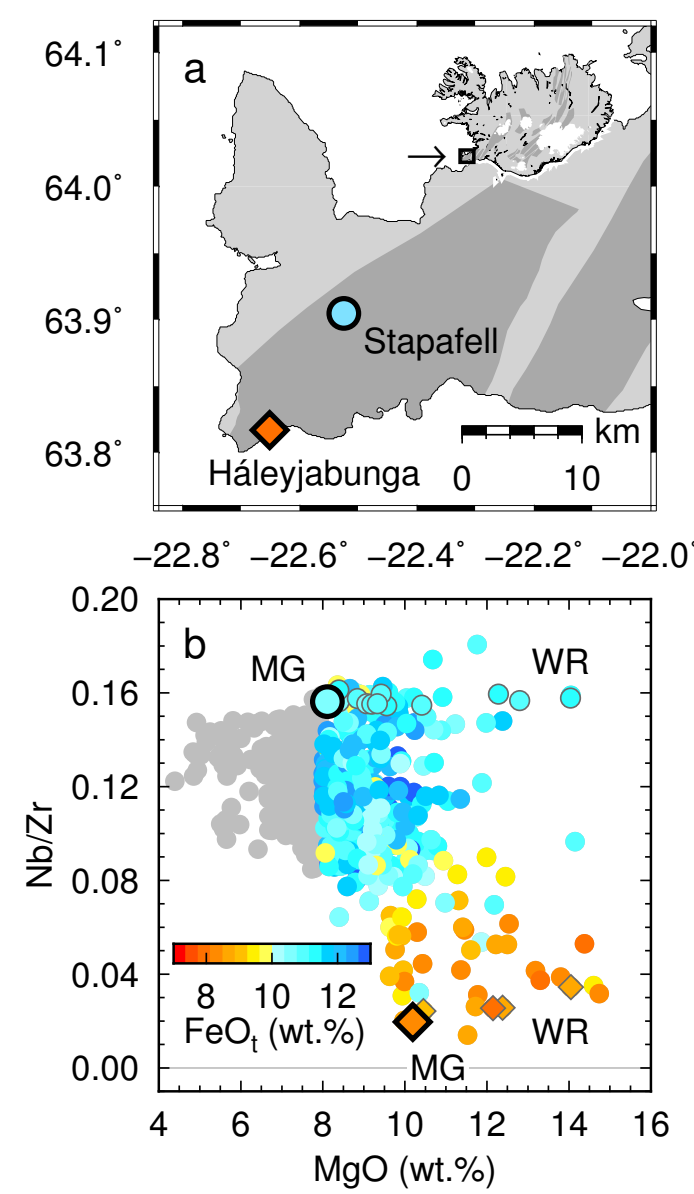

Figure 1: (a) Map showing the location of the Háleyjabunga lava shield and Stapafell subglacial lava flow on the Reykjanes Peninsula of south-west Iceland. The two eruptions are located within the ReykjanesSvartsengi volcanic system, the westernmost sub-aerial expression of the Mid-Atlantic Ridge on Iceland; dark grey fields show the outlines of different volcanic systems. (b) Combined major- and trace-element systematics of whole-rock and matrix glass samples from the Reykjanes Peninsula and Western Volcanic Zone of Iceland (Shorttle and Maclennan, 2011). Samples with $\mathrm{MgO}$ contents above 8 wt.\% are coloured by their $\mathrm{FeO}_{\mathrm{t}}$ contents to illustrate how major element variability correlates with incompatible trace element (ITE) enrichment. Whole-rock compositions from Háleyjabunga and Stapafell are shown as small outlined diamonds and circles respectively (WR; Hémond et al., 1993; Hardarson et al., 1997; Thirlwall et al., 2004, 2006; Peate et al., 2009). Average matrix glass compositions are shown as large outlined symbols (MG; Condomines et al., 1983; Gurenko and Chaussidon, 1995; Peate et al., 2009). Analytical uncertainties are comparable in size to the symbols. 

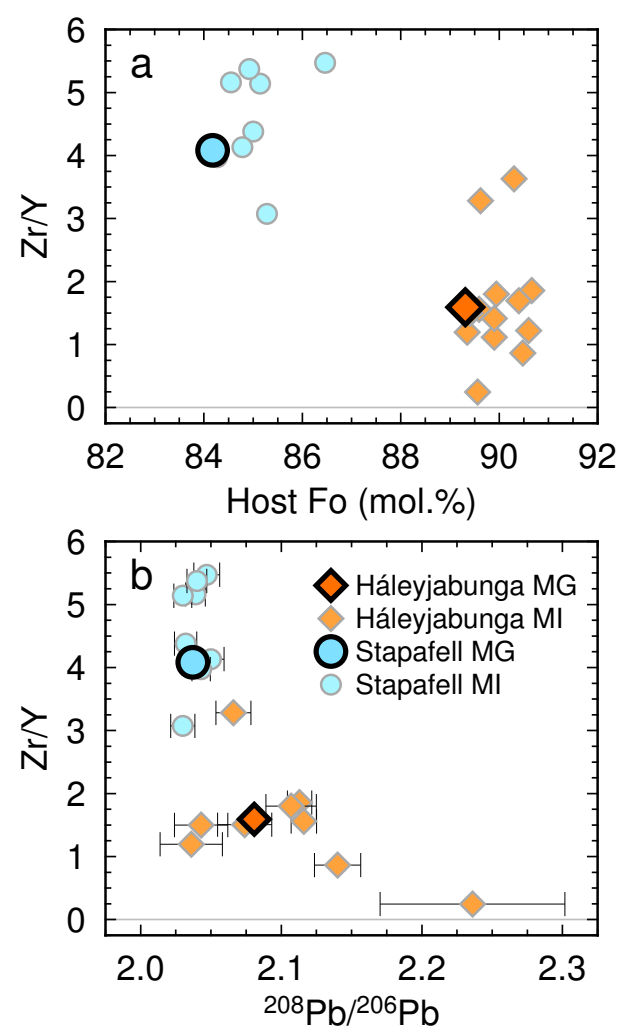

Figure 2: Plots summarising observations made on olivine-hosted melt inclusions (MI) from Háleyjabunga and Stapafell by Maclennan (2008b). Matrix glass (MG) compositions are shown for comparison (see Figure 1 for data sources). $1 \sigma$ uncertainties in trace element compositions and host olivine forsterite contents are comparable in magnitude to the symbol sizes. $1 \sigma$ errors in $\mathrm{Pb}$ isotope compositions are shown. 

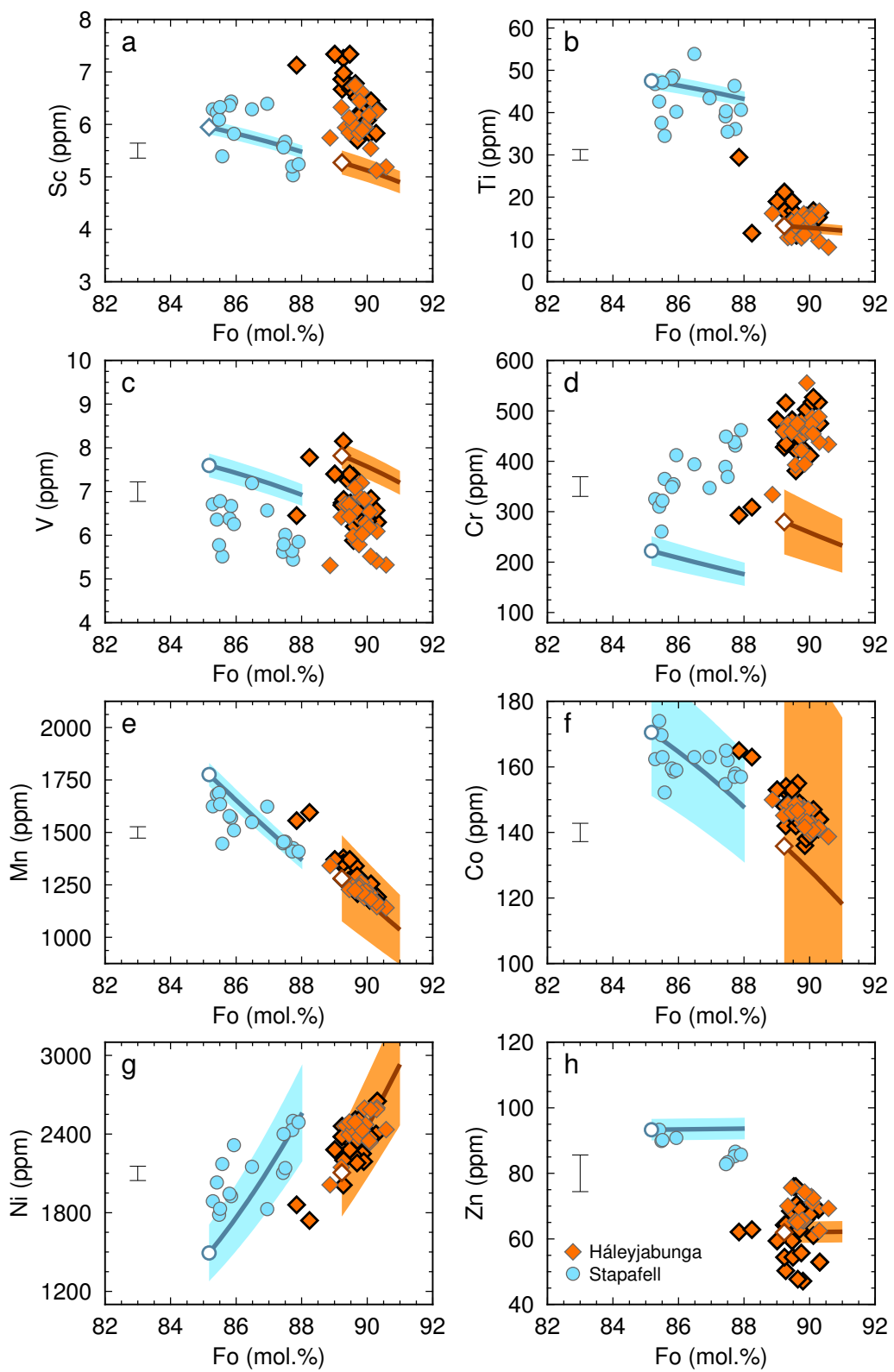

Figure 3: Plots summarising first row transition element (FRTE) systematics in olivine macrocrysts from Háleyjabunga and Stapafell. Macrocrysts in which melt inclusions were also analysed are shown with black outlines. $2 \sigma$ analytical errors are shown for FRTEs. Thick lines show olivine compositions lying on reverse crystallisation paths calculated by incrementally adding equilibrium olivine compositions to estimated matrix glass compositions. Matrix glass trace element compositions were estimated using a regression approach described in Appendix C, and are shown as open symbols. Coloured fields show the effects of propagating errors in estimated matrix glass compositions into crystallisation paths. Sources of $D^{\text {ol-liq }}$ values used to calculate olivine compositions are provided in Table 1. 

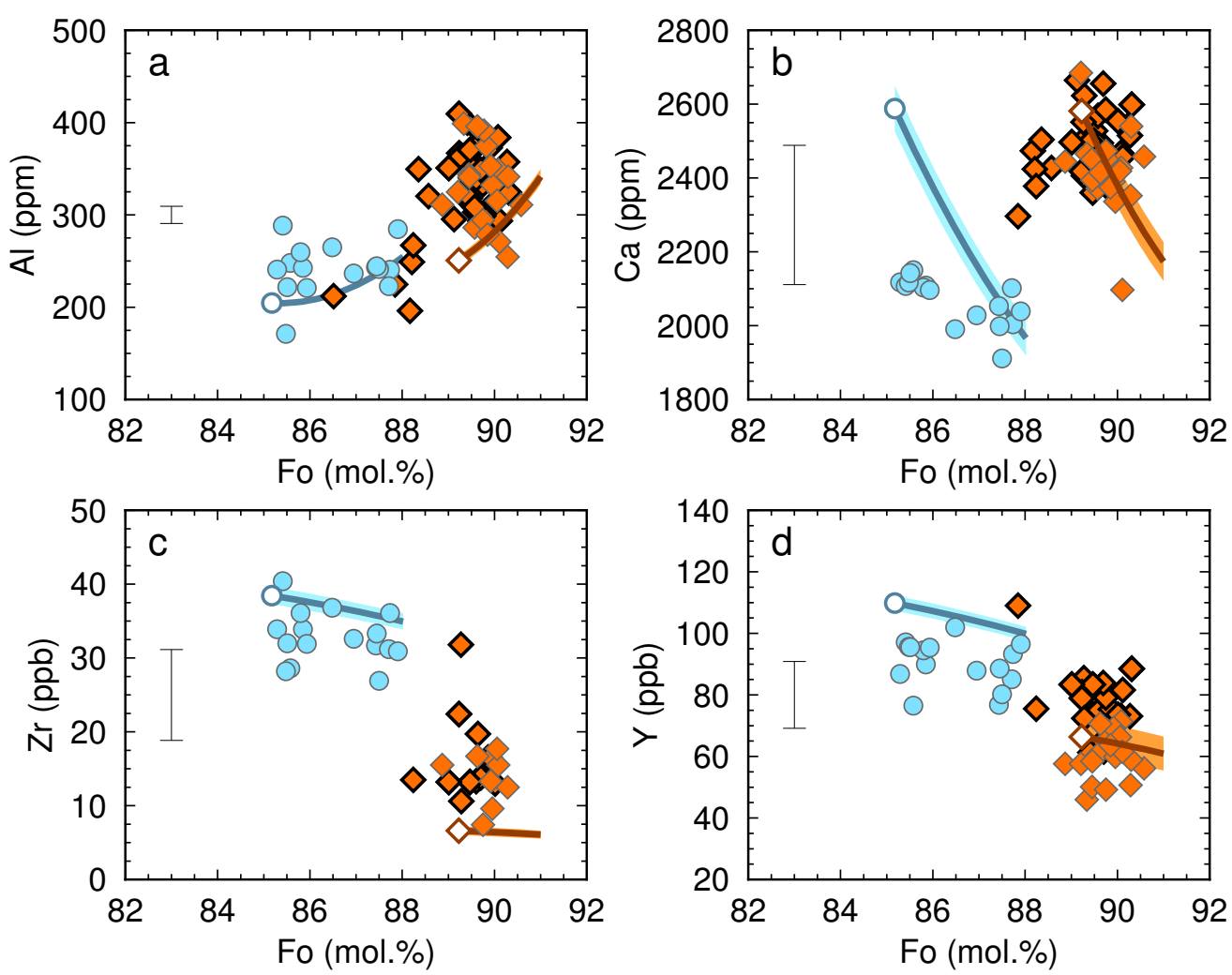

Figure 4: Plots summarising further minor and trace element systematics in olivine macrocrysts from Háleyjabunga and Stapafell. Symbols are the same as in Figure 3. 

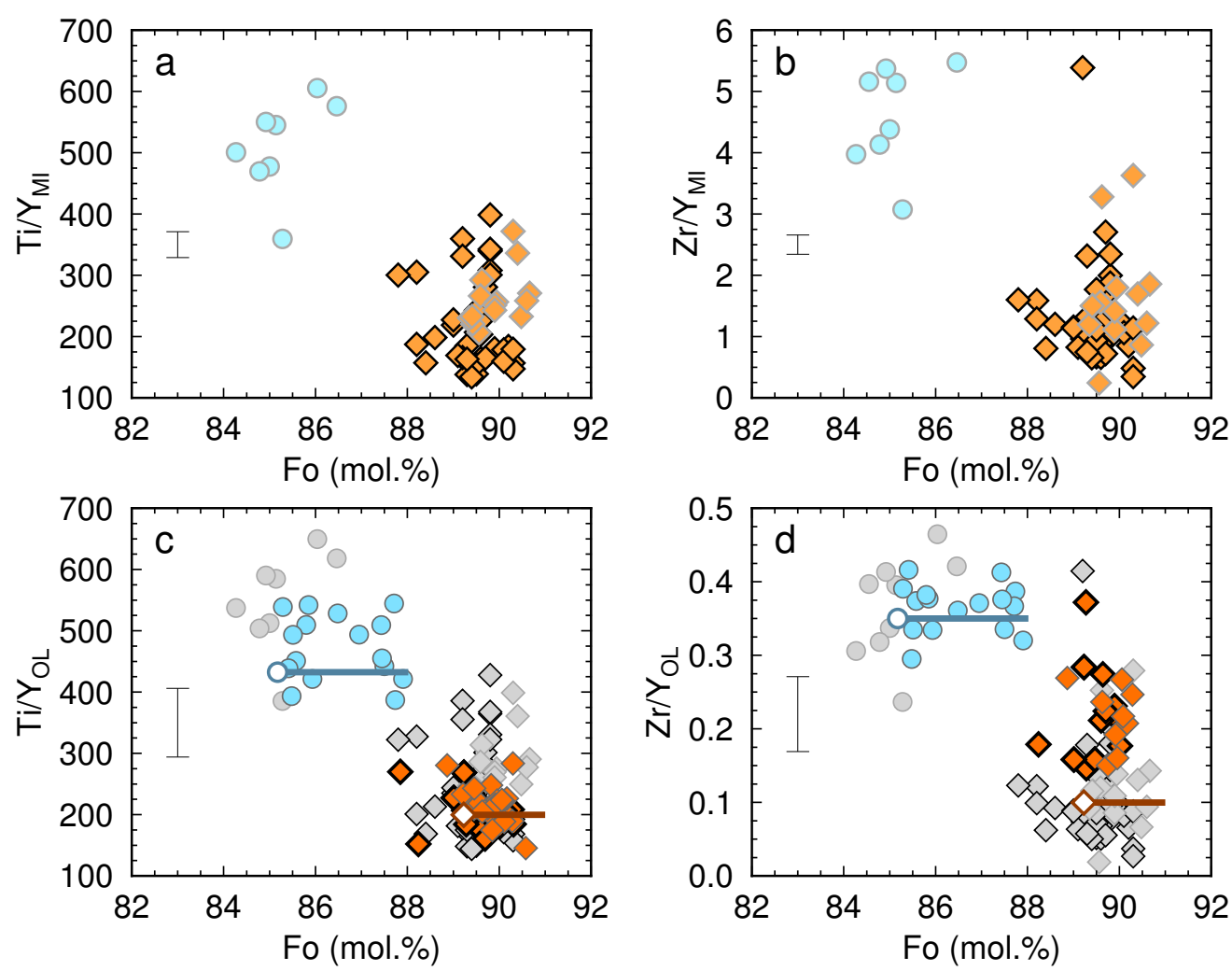

Figure 5: (a and b) Plots summarising trace element systematics in melt inclusions (MI). New data for Háleyjabunga are shown with black outlines; data from Maclennan (2008b) are outlined in grey. $2 \sigma$ analytical errors in melt inclusion compositions are shown. (c and d) Plots comparing trace element systematics in olivine macrocrysts (ol; shown using the same coloured symbols as in Figure 3) with melt inclusion compositions converted into equilibrium olivine compositions using $D^{\text {ol-liq }}$ values provided in Table 1 (shown using grey symbols outlined as in (a) and (b)). Thick lines show reverse crystallisation paths as in Figures 3 and 4. Note that approximately half of the Zr analyses in olivine macrocrysts from Háleyjabunga were below the detection limit and are consequently not shown. $2 \sigma$ analytical errors in olivine compositions are shown. 

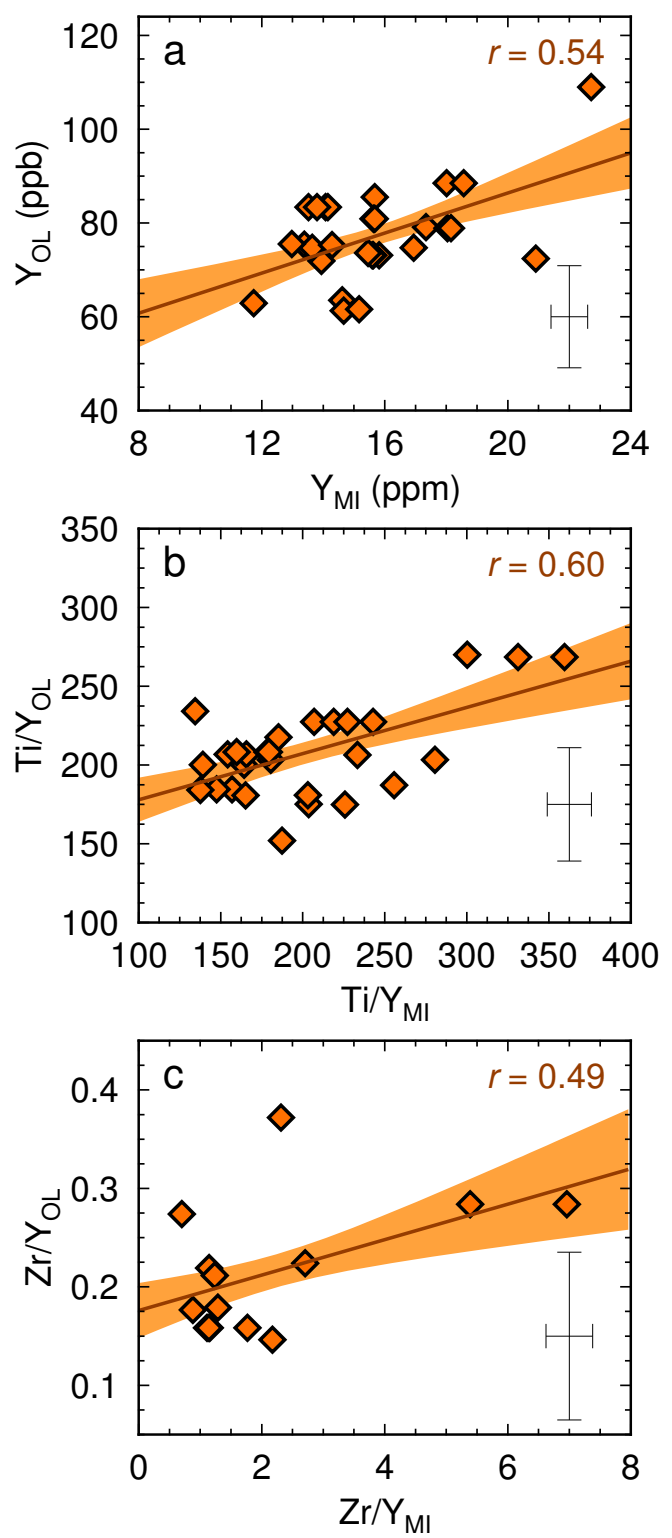

Figure 6: Relationships between the trace element content of olivine macrocrysts (ol) from Háleyjabunga and melt inclusions they host (MI). Orange fields represent simulations where the data have been randomly re-sampled according to analytical uncertainties to indicate the stability of regressions through them. Dark orange lines represent the mean results of these simulations. Correlation coefficients ( $r$-values) are provided alongside $2 \sigma$ analytical errors. 

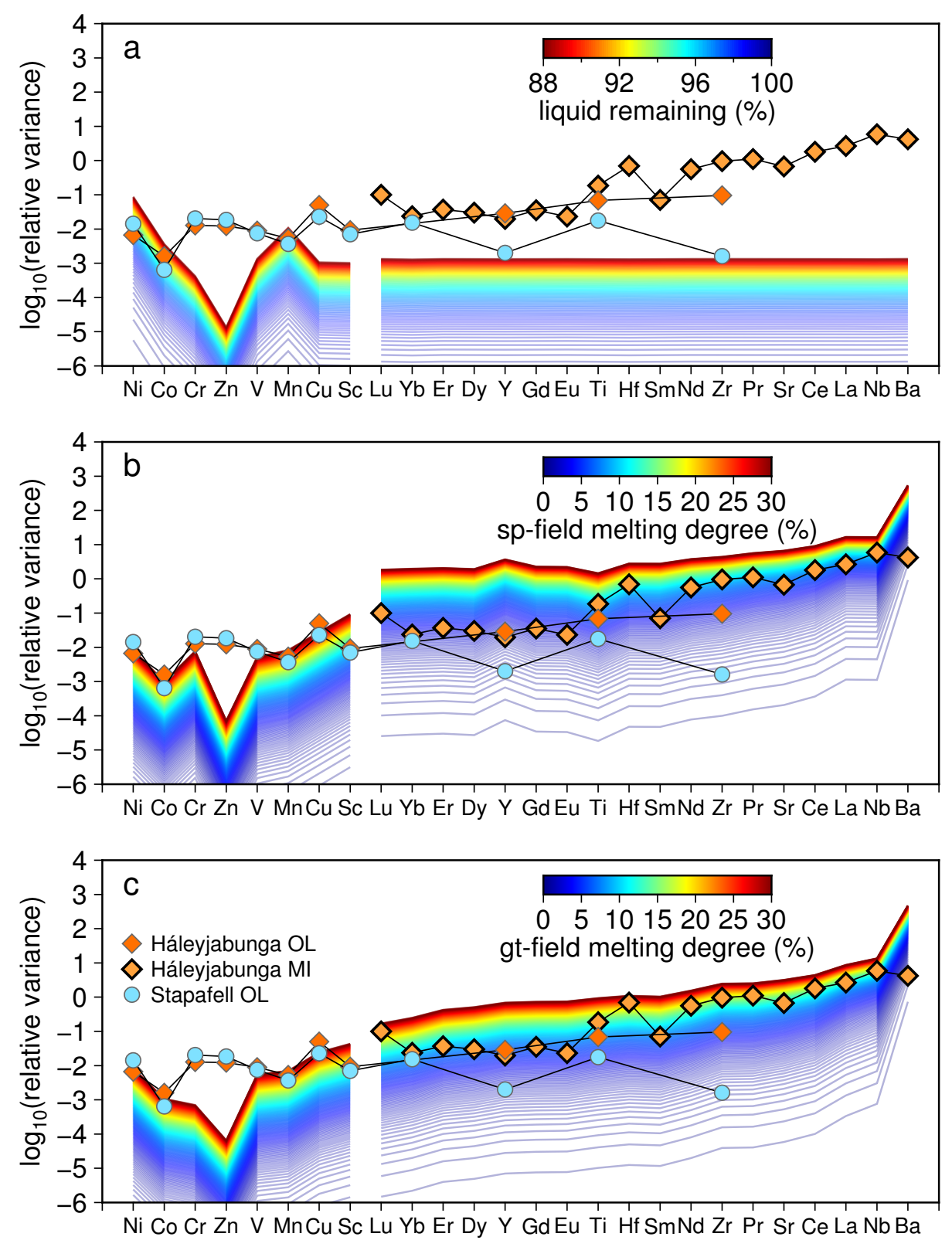

Figure 7: Comparison of the relative variance of trace elements in Háleyjabunga and Stapafell olivines, and Háleyjabunga melt inclusions. The same data are shown in all panels: orange diamonds with thin and thick outlines indicate olivine and melt inclusion data from Háleyjabunga respectively, and blue circles indicate olivine data from Stapafell. These data are overlain onto curves showing the relative variability of trace elements predicted to result from fractional crystallisation (a, equation 8), spinel-field mantle melting (b, equation 4), and garnet-field mantle melting (c, equation 4). Curves are coloured by the remaining liquid fraction (a) or the degree of melting (b and c). Uncertainties are smaller than the symbols. 

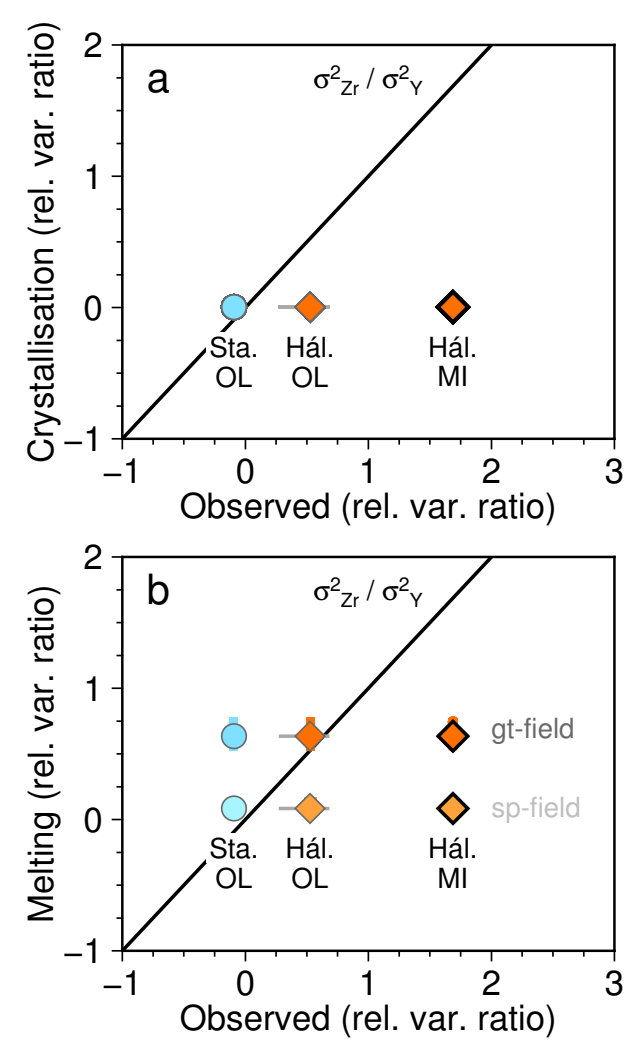

Figure 8: Observed relative variance ratios of $\mathrm{Zr}$ and $\mathrm{Y}$ compared with predictions from fractional crystallisation (a) and fractional melting (b). Calculating variance ratios mitigates the effect of magma mixing on raw variances (shown in Fig. 7). Horizontal grey bars show the $2 \sigma$ uncertainties on observed relative variance ratios. Large symbols in (b) show the predicted relative variance ratio at $20 \%$ melting and vertical bars the full range of variance present in incremental melts resulting from $1 \%$ to $30 \%$ melting. 


\begin{tabular}{|c|c|c|c|c|c|}
\hline Element & Minimum value & Maximum value & Constant value & Source & Reported values $( \pm 1 \sigma)$ \\
\hline $\mathrm{Al}$ & $5.09 \times 10^{-03}$ & $8.28 \times 10^{-03}$ & & Herzberg and O'Hara (2002) & \\
\hline $\mathrm{Ca}$ & $2.33 \times 10^{-02}$ & $2.88 \times 10^{-02}$ & & Herzberg and O'Hara (2002) & \\
\hline $\mathrm{Sc}$ & & & 0.14 & Beattie (1994) & $0.13 \pm 0.01$ \\
\hline \multirow[t]{2}{*}{$\mathrm{Ti}$} & & & $4.50 \times 10^{-03}$ & Mallmann and O'Neill (2009) & $5.30 \pm 0.15 \times 10^{-03}$ \\
\hline & & & & Spandler and O'Neill (2010) & $1.90 \pm 0.13 \times 10^{-03}$ \\
\hline $\mathrm{V}$ & $2.41 \times 10^{-02}$ & $3.73 \times 10^{-02}$ & & Canil (1997) & $\left(f_{\mathrm{O}_{2}}\right.$-dependent $)$ \\
\hline $\mathrm{Cr}$ & 0.41 & 0.52 & & Herzberg and O'Hara (2002) & \\
\hline Mn & 0.84 & 1.20 & & Herzberg and O'Hara (2002) & \\
\hline Co & 2.28 & 3.58 & & Beattie et al. (1991) & \\
\hline $\mathrm{Ni}$ & 7.69 & 13.2 & & Beattie et al. (1991) & \\
\hline $\mathrm{Cu}$ & & & 0.11 & Gaetani and Grove (1997) & $0.11 \pm 0.04$ \\
\hline $\mathrm{Zn}$ & & & 1.04 & Kohn and Schofield (1994) & (NBO/T-dependent) \\
\hline \multirow[t]{2}{*}{$\mathrm{Y}$} & & & $4.50 \times 10^{-03}$ & Beattie (1994) & $4.94 \pm 0.15 \times 10^{-03}$ \\
\hline & & & & Spandler and O'Neill (2010) & $3.60 \pm 0.29 \times 10^{-03}$ \\
\hline $\mathrm{Zr}$ & & & $3.80 \times 10^{-04}$ & Spandler and O'Neill (2010) & $3.80 \pm 0.35 \times 10^{-04}$ \\
\hline $\mathrm{Yb}$ & & & $1.84 \times 10^{-02}$ & Beattie (1994) & $1.84 \pm 0.09 \times 10^{-02}$ \\
\hline
\end{tabular}

Table 1: Summary of $D^{\text {ol-liq }}$ values, models and sources used during forward and analytical modelling of fractional crystallisation.

\section{Appendix A. Details of analytical methods}

\section{Appendix A.1. Electron probe microanalysis (EPMA)}

Olivine macrocrysts were analysed with a Cameca SX100 at the University of Cambridge, $\mathrm{UK}$, using a $1 \mu \mathrm{m}$ beam and an operating potential of $15 \mathrm{kV}$. Major elements ( $\mathrm{Si}, \mathrm{Fe}$ and $\mathrm{Mg}$ ) were measured with a beam current of $20 \mathrm{nA}$ and minor elements (Al, Cr, Mn, Ca, P and $\mathrm{Ni}$ ) were measured with a beam current of $100 \mathrm{nA}$. Major elements were counted on peak for 20 s. Minor elements were counted on peak for the following durations: Al, $450 \mathrm{~s}$; Cr, 120 s; Mn, $120 \mathrm{~s}$; Ca, $300 \mathrm{~s} ; \mathrm{P}, 450 \mathrm{~s}$; and Ni, $240 \mathrm{~s}$. Background counting times were half the peak counting times for each element. The following compositions were used as calibration standards: diopside for $\mathrm{Si}$ and $\mathrm{Ca}$, corundum for $\mathrm{Al}, \mathrm{Cr}$ metal for $\mathrm{Cr}$, fayalite for $\mathrm{Fe}, \mathrm{Mn}$ metal for Mn, St. John's olivine for $\mathrm{Mg}$, apatite for $\mathrm{P}$ and $\mathrm{NiO}$ for Ni. Measurements of the San Carlos olivine standard (NMNH 111312-44; Jarosewich et al., 1980) indicate that major element and $\mathrm{Ni}$ analyses were accurate to better than $1.5 \%$ relative, and that $\mathrm{Mn}$ analyses were accurate to better than $6 \%$ relative (Supplementary Material). Repeat analyses of 
unknowns indicate that major elements were determined with $1 \sigma$ relative precisions better than $1 \%$, while minor elements were determined with $1 \sigma$ relative precisions ranging from $1.5 \%$ for Ni to $32 \%$ for Cr (Supplementary Material).

Olivine-hosted melt inclusions were also analysed with a Cameca SX100 at the University of Cambridge, UK, using a $10 \mu \mathrm{m}$ beam, an operating potential of $15 \mathrm{kV}$ and a beam current of $6 \mathrm{nA}$. Elements were counted on peak for the following durations: $\mathrm{Si}, 20 \mathrm{~s}$; Ti, $60 \mathrm{~s} ; \mathrm{Al}, 30 \mathrm{~s} ; \mathrm{Fe}, 20 \mathrm{~s} ; \mathrm{Mn}, 30 \mathrm{~s} ; \mathrm{Mg}, 20 \mathrm{~s} ; \mathrm{Ca}, 60 \mathrm{~s} ; \mathrm{Na}, 10 \mathrm{~s} ; \mathrm{K}, 10 \mathrm{~s} ; \mathrm{P}, 60 \mathrm{~s} ;$ and S, 90 s. Background counting times were half the peak counting times for each element. The following compositions were used as calibration standards: diopside for $\mathrm{Si}$ and $\mathrm{Ca}$, corundum for $\mathrm{Al}$, Cr metal for Cr, fayalite for Fe, Mn metal for Mn, St. John's olivine for Mg, jadeite for Na, K-feldspar for K, apatite for P and celestine for S. Measurements of the GOR128-G glass standard standard indicate that individual analyses were accurate to better than $6 \%$ relative, and that major and minor elements were determined with $1 \sigma$ relative precisions better than $2 \%$ and $13 \%$ respectively (Supplementary Material).

A small number of Cr-spinel macrocrysts were analysed with a Cameca SX100 at the Leibniz Universität Hannover, Germany, using a $1 \mu \mathrm{m}$ beam, an operating potential of 15 $\mathrm{kV}$ and a beam current of $15 \mathrm{nA}$. All elements ( $\mathrm{Si}, \mathrm{Ti}, \mathrm{Al}, \mathrm{Cr}, \mathrm{Fe}, \mathrm{Mn}, \mathrm{Mg}, \mathrm{Ca}$ and $\mathrm{Na}$ ) were counted on peak for $20 \mathrm{~s}$ and off peak for $10 \mathrm{~s}$ apart from $\mathrm{Na}$, which was counted for 10 s on peak. Measurements of a chromite standard (NMNH 117075; Jarosewich et al., 1980) indicate that major element analyses were accurate to better than $5 \%$ relative.

X-ray maps of two olivines from Stapafell were produced with a Cameca SX100 at the Leibniz Universität Hannover, Germany, using a setup similar to that described by Shea et al. (2015). Mg, Al, Ni, Ca and P intensities were mapped using an operating potential of $20 \mathrm{kV}$, a beam current of $300 \mathrm{nA}$, a dwell time of $200 \mu$ s and a pixel spacing of $2 \mu \mathrm{m}$. Similar maps of one olivine from Háleyjabunga were were produced with a Cameca SX100 at the University of Cambridge, UK, using a beam current of $200 \mathrm{nA}$, a dwell time of $500 \mu \mathrm{s}$ and a pixel spacing of $3 \mu \mathrm{m}$. 


\section{Appendix A.2. Laser ablation inductively-coupled mass spectrometry (LA-ICP-MS)}

Olivine macrocrysts were analysed with a ThermoScientific ElementXR fast-scanning sector-field ICP-MS coupled to a laser ablation system based on a Spectra Physics Solstice $194 \mathrm{~nm}$ femstosecond (fs) laser at the Leibniz Universität Hannover, Germany. Samples were ablated by rastering a $30 \mu \mathrm{m}$ laser spot over areas of $100 \times 100 \mu \mathrm{m}$ with a laser repetition rate of $20 \mathrm{~Hz}$ following the principles outlined by Horn et al. (2006). During analysis, ablated material was transported to the ICP-MS in He that was mixed with Ar before entering the plasma torch. The following isotopes were then measured using the ICP-MS in low mass resolution mode: ${ }^{27} \mathrm{Al},{ }^{29} \mathrm{Si},{ }^{31} \mathrm{P},{ }^{43} \mathrm{Ca},{ }^{45} \mathrm{Sc},{ }^{47} \mathrm{Ti},{ }^{49} \mathrm{Ti},{ }^{51} \mathrm{~V},{ }^{53} \mathrm{Cr},{ }^{55} \mathrm{Mn},{ }^{59} \mathrm{Co},{ }^{60} \mathrm{Ni},{ }^{63} \mathrm{Cu}$, ${ }^{66} \mathrm{Zn},{ }^{89} \mathrm{Y},{ }^{90} \mathrm{Zr}$ and ${ }^{172} \mathrm{Yb}$. Five mass lines were each measured for $5 \mathrm{~ms}$ in the peak centres of each isotope, resulting in a total sweep time of $\sim 1 \mathrm{~s}$. Oxide formation rates were monitored by measuring $\mathrm{ThO} / \mathrm{Th}$ ratios, which were always $0.1-0.4 \%$. Signals were acquired for a total of $120 \mathrm{~s}$ per analysis with the laser off for the first $40 \mathrm{~s}$ in order to determine background count rates. Note that samples were pre-rastered before analysis to remove surface contamination. A 120 s gas rinse-out time was used after pre-rastering to allow element signals to return to baseline levels. $\mathrm{SiO}_{2}$ contents determined by EPMA were used as an internal standard $\left({ }^{29} \mathrm{Si}\right.$ ), and the BIR-1G glass standard was used for quantification (Jochum et al., 2006). Measurements of the BCR-2G glass standard indicate that most elemental analyses were accurate to better than $10 \%$ relative, with only $\mathrm{P}, \mathrm{Cr}$ and $\mathrm{Cu}$ returning deviations of $>10$ $\%$ relative (Supplementary Material; Jochum et al., 2006). However, poorly-quantified P was only used to monitor for the presence of cryptic zoning in olivine (e.g., Milman-Barris et al., 2008), and $\mathrm{Cr}$ and $\mathrm{Cu}$ are present at concentrations approaching their detection limits in BCR-2G. Repeat analyses of a San Carlos olivine (though not from the NMNH 111312-44 aliquot) indicate that all elements apart from $\mathrm{Zr}$ were determined with $1 \sigma$ relative precisions better than $\sim 7 \%$ : Zr and $\mathrm{Yb}$, which were only present at $\sim 30 \mathrm{ppb}$, were determined with $1 \sigma$ relative precisions of $\sim 17 \%$ (Supplementary Material). 


\section{Appendix A.3. Secondary ion mass spectrometry (SIMS)}

Olivine-hosted melt inclusions were analysed with a Cameca ims-5f in Okayama University, Japan. Measurements were made using a $\mathrm{O}^{-}$ion beam with an accelerating potential of $17.5 \mathrm{keV}$, a beam current of $10 \mathrm{nA}$ and a secondary accelerating voltage of $4500 \mathrm{~V}$ minus a $45 \mathrm{~V}$ offset. The following isotopes were measured for 10 cycles (counting times in seconds in parentheses): ${ }^{7} \mathrm{Li}(10),{ }^{30} \mathrm{Si}(5),{ }^{88} \mathrm{Sr}(15),{ }^{89} \mathrm{Y}(15),{ }^{90} \mathrm{Zr}(15),{ }^{93} \mathrm{Nb}(15),{ }^{137} \mathrm{Ba}(20),{ }^{139} \mathrm{La}(20)$, ${ }^{140} \mathrm{Ce}(20),{ }^{141} \mathrm{Pr}(20),{ }^{146} \mathrm{Nd}(20),{ }^{147} \mathrm{Sm}(20),{ }^{151} \mathrm{Eu}(20),{ }^{160} \mathrm{Gd}(20),{ }^{163} \mathrm{Dy}(20),{ }^{167} \operatorname{Er}(20),{ }^{174} \mathrm{Yb}(20)$, ${ }^{175} \mathrm{Lu}(20),{ }^{178} \mathrm{Hf}(20)$. $\mathrm{SiO}_{2}$ contents determined by EPMA were used as an internal standard $\left({ }^{30} \mathrm{Si}\right)$, and three to four in-house reference materials were used for forming calibration curves for quantification: gh_tahiti, gl_dr1a1, cpx_sax39, and opx_klb1. Measurements of various materials indicate that most elemental analyses were accurate to better than $10 \%$ relative. Repeat analyses of the GOR128-G glass standard indicate that all elements apart from Hf and Dy were determined with $1 \sigma$ relative precisions better than $10 \%$; Hf and Dy were determined with $1 \sigma$ relative precisions of $34 \%$ and $11 \%$ respectively (Supplementary Material; Jochum et al., 2005).

\section{Appendix B. The effect of diffusion on element systematics}

Crystal-melt disequilibrium arising from mixing or differentiation results in diffusive reequilibration, whereby crystal compositions approach being in equilibrium with their carrier melts at rates mediated by the diffusivities of the species that are out of equilibrium (e.g., Costa and Morgan, 2010). Given that diffusive re-equilibration is thought to play an important role in controlling the forsterite content distribution of olivine macrocrysts from primitive Icelandic eruption (Thomson and Maclennan, 2013), it is important to consider whether diffusion could have played a role in generating the element systematics observed in olivine macrocrysts from the Reykjanes Peninsula. Forward modelling calculations were thus performed to evaluate how the mean core composition of olivines from the Háleyjabunga eruption would respond to undergoing diffusive re-equilibration with their carrier melt. Normalised 1D profiles resulting from an arbitrary 48 years of diffusion over a distance of 1000 
$\mu \mathrm{m}$ at $3 \mathrm{kbar}, 1200{ }^{\circ} \mathrm{C}$ and half a log unit above the QFM buffer are shown in Figure B.9a. Diffusivities (parallel to [001] where relevant) were derived from models of Dohmen et al. (2007) for Fe-Mg and Mn, Coogan et al. (2005) for Ca, Petry et al. (2004) for Ni, and Cherniak and Liang (2014) for Ti. Incomplete re-equilibration, which is a necessary condition for generating variability by diffusion, fractionates elements based on their relative diffusivities $(\mathrm{Fe}-\mathrm{Mg} \sim \mathrm{Mn}>\mathrm{Ni}>\mathrm{Ca}>\mathrm{Ti}$; Fig. B.9a). In turn, this diffusive fractionation results in complex, non-linear relationships between elements that differ in sense and strength from those present in our natural data. For example, natural Mn and Ni data define a much shallower trend than predicted from incomplete diffusion (Fig. B.9b). Moreover, because diffusion cannot account for the Mn-Ni systematics we observe, it seems improbable that variations in slowly diffusing elements such as Ti could have been generated by diffusion. 

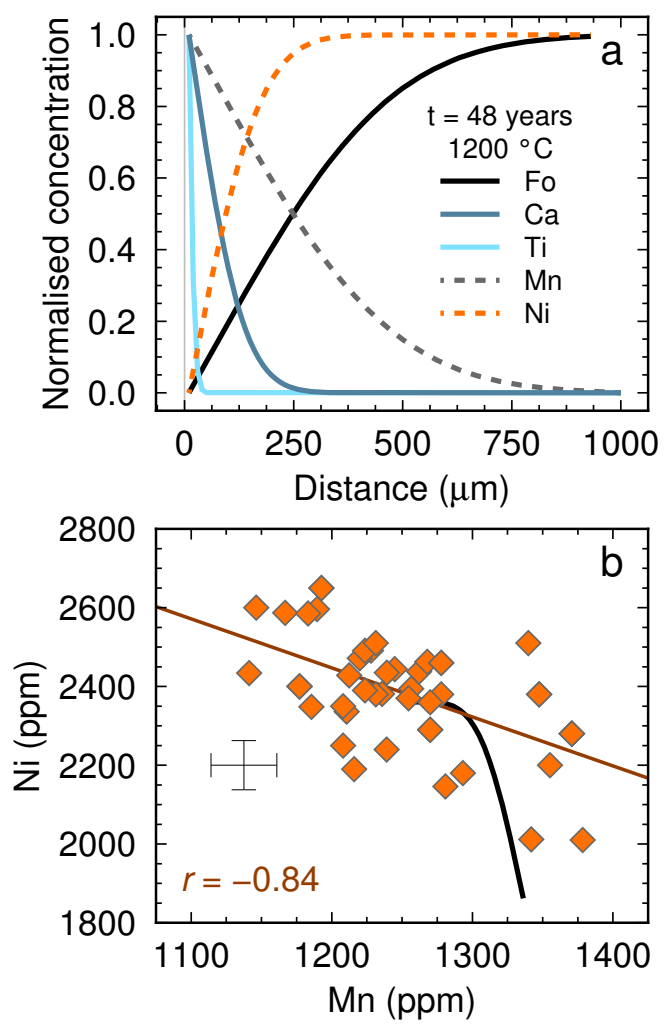

Figure B.9: (a) Normalised diffusion profiles resulting from equilibrating the mean composition of olivine cores from Háleyjabunga with their carrier liquid. (b) $\mathrm{Mn}-\mathrm{Ni}$ systematics resulting from diffusive reequilibration (shown as a black line) compared with with natural data from Háleyjabunga. A regression through the natural data is shown in dark orange. A correlation coefficient ( $r$-value) is provided alongside $2 \sigma$ analytical errors.

\section{Appendix C. Estimating matrix glass trace element contents}

Matrix glass analyses from the Háleyjabunga and Stapafell eruptions are sparse (Conof FTREs, which are crucial to this study, are of uncertain quality or absent entirely. Fortunately, high quality whole-rock analyses from both eruptions are more numerous (Hémond et al., 1993; Hardarson et al., 1997; Gee et al., 1998; Skovgaard et al., 2001; Thirlwall et al., 2004, 2006; Fitton et al., 2003; Peate et al., 2009). We therefore estimated matrix glass trace element contents from whole-rock compositions using a regression approach. By assuming that variability in whole-rock compositions is controlled by the accumulation of composi- 
tionally homogeneous macrocrysts (i.e. olivines), matrix glass trace element contents were estimated by regressing whole-rock trace elements against accumulation-sensitive $\mathrm{MgO}$ after filtering the dataset for poor quality analyses (i.e. analyses that deviated significantly from an olivine control line). Despite being subject to uncertainties in whole-rock compositions, this approach provides an internally consistent way of estimating matrix glass trace element contents. In cases where trace element data are available, estimated matrix glass concentrations are generally within $10 \%$ of published values (e.g., Gurenko and Chaussidon, 1995), though concentrations diverge when either whole-rock data are sparse or reported errors in glass analyses are larger than $10 \%$. Uncertainties in regression coefficients were thus used to propagate errors from the regression procedure into the calculated matrix glass compositions used for modelling fractional crystallisation.

\section{Appendix D. The effect of Cr-spinel crystallisation on olivine compositions}

The effect of Cr-spinel formation on the composition of co-crystallising olivine macrocrysts was investigated by modifying the crystallisation model described in the main text. Namely, we estimated fractionation paths resulting from the co-crystallisation of olivine and Cr-spinel. However, predicting equilibrium Cr-spinel compositions from melt compositions is challenging because of the spinel group's complex solid solutions (e.g., Poustovetov and Roeder, 2001). We therefore used average Cr-spinel core compositions from Háleyjabunga and Stapafell for our modelling (Supplementary Material). Approximate partition coefficients for $\mathrm{Cr}$ were estimated by assuming that measured Cr-spinel crystals were in equilibrium with their respective matrix glass compositions. Further partition coefficients were sourced from Horn et al. (1994) and Righter et al. (2006). Olivine and Cr-spinel were assumed to crystallise in a 54:1 ratio based on the average $>\mathrm{Fo}_{80}$ olivine-to-Cr-spinel ratio in QEMSCAN images (Supplementary Material). Despite V, Co and Ni being compatible in Cr-spinel (Righter et al., 2006), our calculations demonstrate that their abundances in olivine macrocrysts are largely unaffected by the co-crystallisation of Cr-spinel (Figs. D.10a, D.10c and D.10d). Cr is strongly affected, however, and the positive correlations between olivine forsterite and $\mathrm{Cr}$ contents observed in our data can be readily accounted for by the 

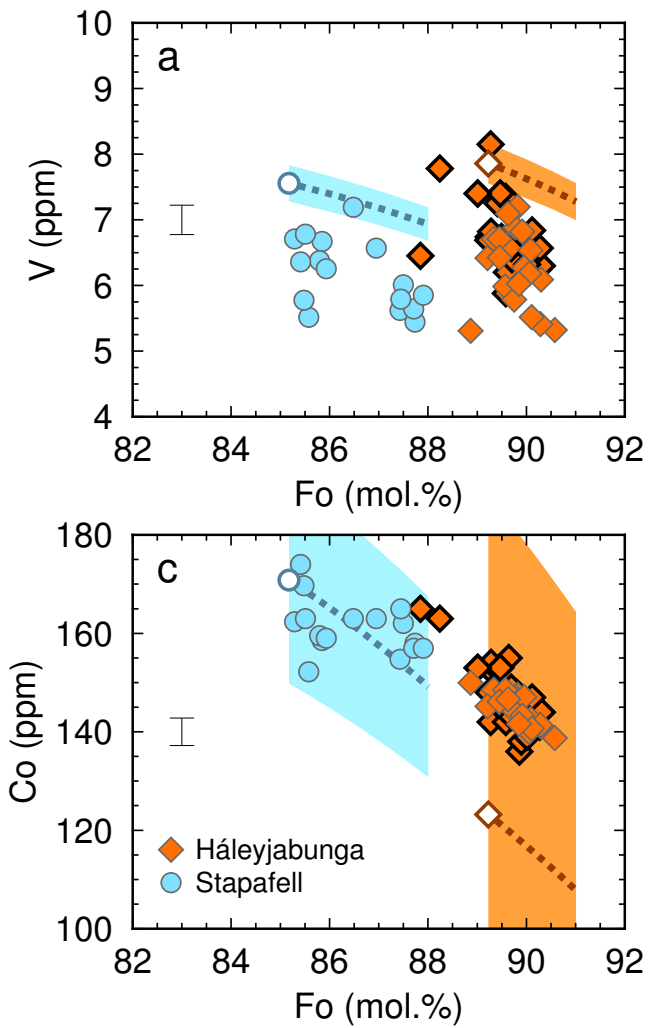
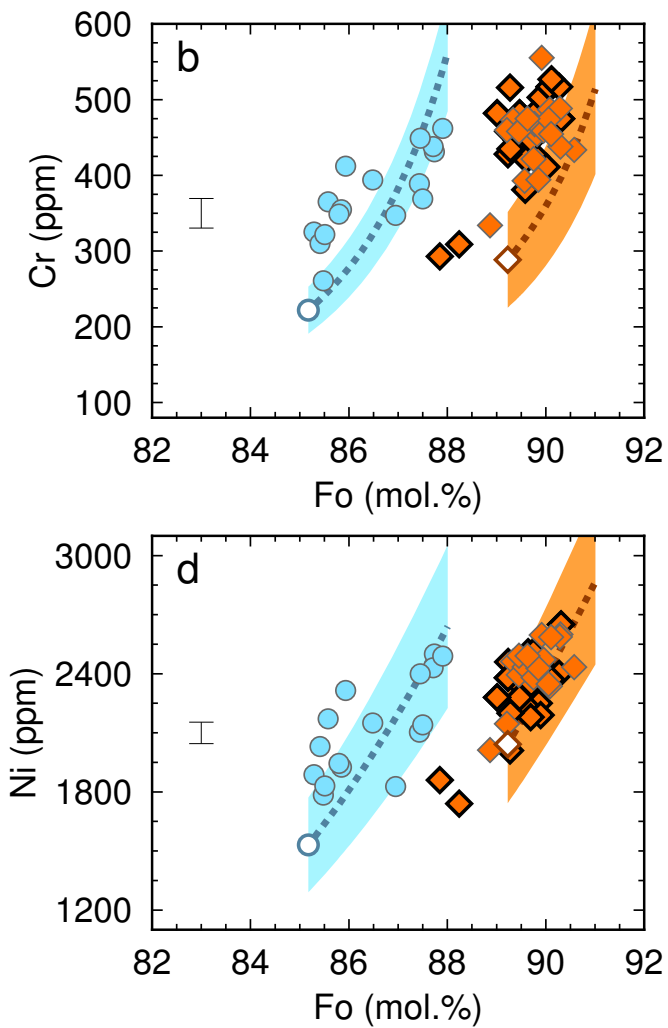

Figure D.10: Plots summarising the effect of including Cr-spinel in our fractional crystallisation model. Mean fractionation paths are plotted using dashed lines. Otherwise, symbols are the same as in Figure 3. 